(2) norden

Entreprenörskap i högre konstnärlig och kreativ utbildning i Norden
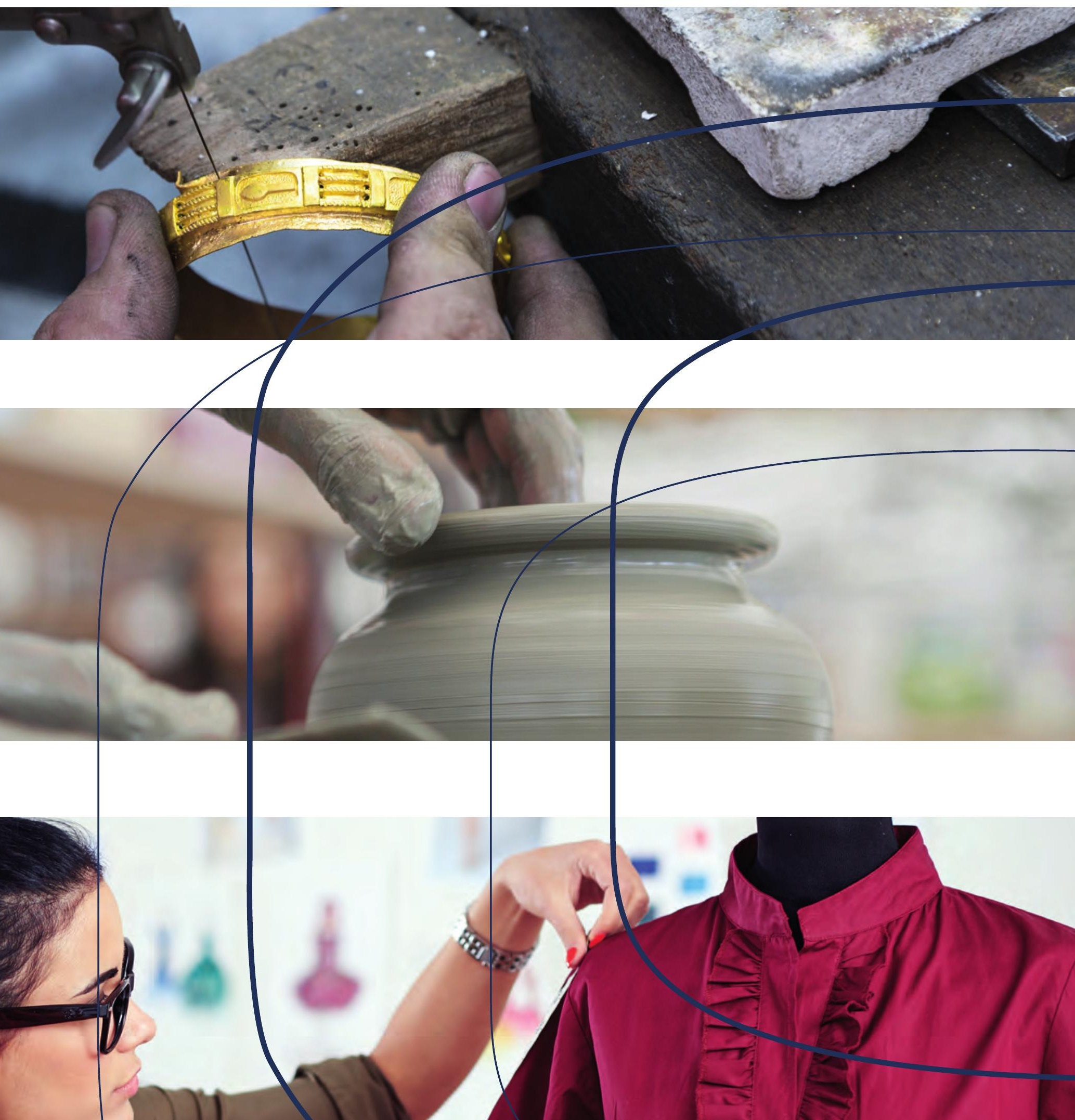

2 norden 



\section{Entreprenörskap i högre konstnärlig och kreativ utbildning i Norden}

Heidi Nilsson och Erik Robertson

TemaNord 2015:550 
Entreprenörskap i högre konstnärlig och kreativ utbildning i Norden

Heidi Nilsson och Erik Robertson

ISBN 978-92-893-4244-5 (PRINT)

ISBN 978-92-893-4246-9 (PDF)

ISBN 978-92-893-4245-2 (EPUB)

http://dx.doi.org/10.6027/TN2015-550

TemaNord 2015:550

ISSN 0908-6692

(C) Nordiska ministerrådet 2015

Layout: Hanne Lebech

Omslagsfoto: ImageSelect

Tryck: Rosendahls-Schultz Grafisk

Printed in Denmark

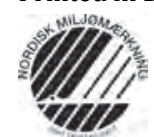

\section{KRR}

NORDIC CREATIVE ELONDMY

Denna rapport är utgiven med finansiellt stöd från Nordiska ministerrådet. Innehållet i rapporten avspeglar inte nödvändigtvis Nordiska ministerrådets synpunkter, åsikter eller rekommendationer.

www.norden.org/nordpub

\section{Det nordiska samarbetet}

Det nordiska samarbetet är ett av världens mest omfattande regionala samarbeten. Det omfattar Danmark, Finland, Island, Norge och Sverige samt Färöarna, Grönland och Åland.

Det nordiska samarbetet är politiskt, ekonomiskt och kulturellt förankrat och är en viktig partner i europeiskt och internationellt samarbete. Den nordiska gemenskapen arbetar för ett starkt Norden i ett starkt Europa.

Det nordiska samarbetet ska stärka nordiska och regionala intressen och värderingar i en global omvärld. Gemensamma värderingar länderna emellan bidrar till att stärka Nordens ställning som en av världens mest innovativa och konkurrenskraftiga regioner.

\section{Nordiska ministerrådet}

Ved Stranden 18

DK-1061 København K

Telefon (+45) 33960200

www.norden.org 


\section{Innehål}

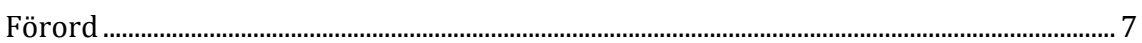

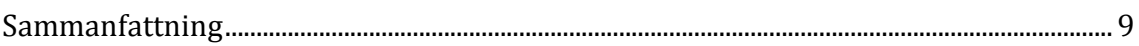

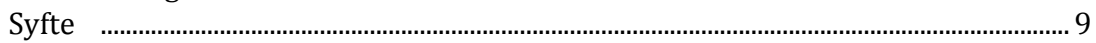

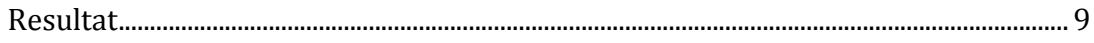

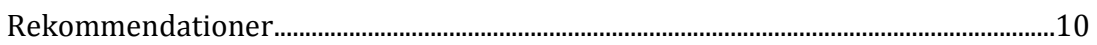

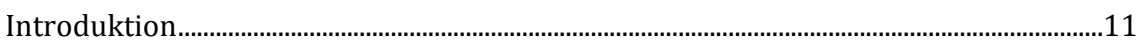

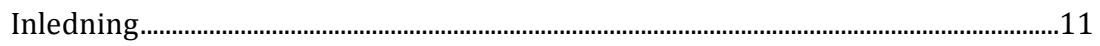

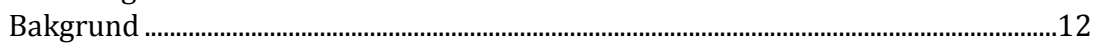

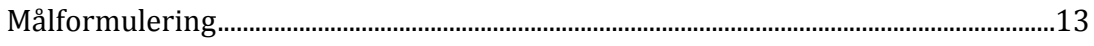

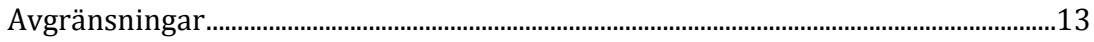

Metod ........................................................................................................................................14

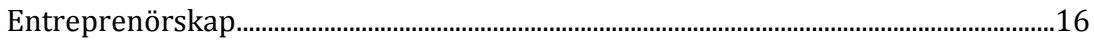

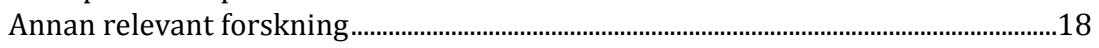

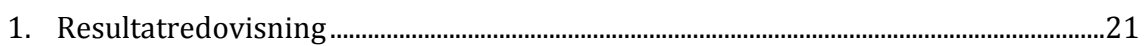

1.1 Danmark ……………………….................................................................................21

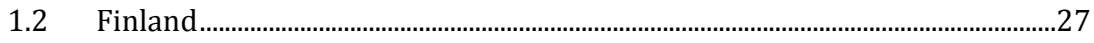

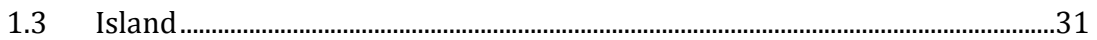

$1.4 \quad$ Norge .................................................................................................................................33

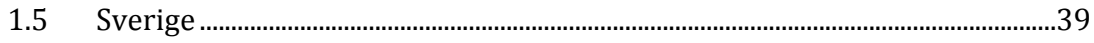

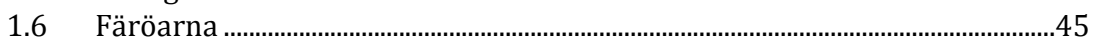

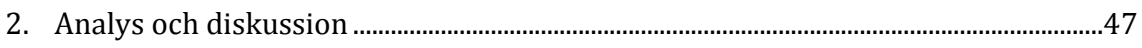

2.1 Entreprenörskapsutbildningens plats i utbildningarna..................................47

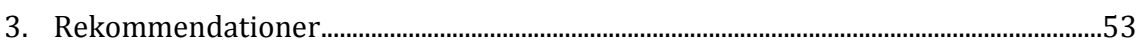

3.1 Fortgående diskussion av begreppet entreprenör och entreprenör-

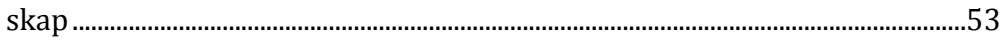

3.2 Utfallet av entreprenörskapsutbildning...........................................................54

3.3 Arbete för ökat intresse för entreprenörskap...................................................55

3.4 Universitets- och högskoleövergripande entreprenörssatsningar................56

3.5 Utveckling av högskole- och universitetsövergripande satsningar................57

3.6 Renodlad entreprenörskapsutbildning ..............................................................58

3.7 Ämnesanpassad entreprenörskapsutbildning ................................................59

3.8 Studentdrivna entreprenörskapssatsningar......................................................60

3.9 Sammanfattning av rekommendationer ..........................................................61

Referenser.............................................................................................................................63

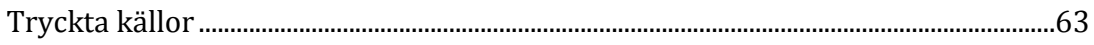

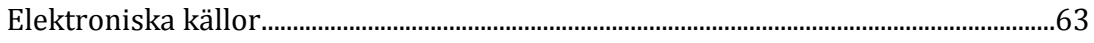

Summary in English ...................................................................................................6

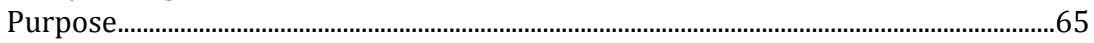

Results.....................................................................................................................................65

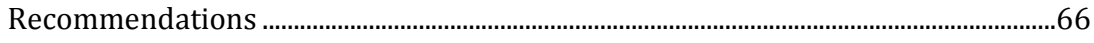

Bilagor.............................................................................................................................6

Webadresser till i rapporten förekommande entreprenör-skapssatsningar för studenter vid universitet och högskolor ...........................................67 



\section{Förord}

Denna rapport har tagits fram av Nordic Game Resources för KreaNord år 2010, och bygger på en kartläggning av utbudet av entreprenörsutbildning inom de högre konstnärliga och kreativa utbildningarna i Norden.

KreaNord kom till år 2008 som en del av Nordiska ministerrådets globaliseringsarbete, med syftet att utveckla och profilera Norden som en arena för kulturella och kreativa näringar. KreaNord har sedan dess etablerat ett tvärsektoriellt policysamarbete mellan kultur- och näringsdepartement och myndigheter i de nordiska länderna, tagit fram kunskapsunderlag, samt drivit flera projekt kring bland annat entreprenörskap i konstnärliga utbildningar och finansieringsfrågor. KreaNord avvecklades under 2015.

I samband med avvecklingen av KreaNord har denna rapport återpublicerats år 2015 tillsammans med en rad andra KreaNord-rapporter. 



\title{
Sammanfattning
}

\author{
Syfte
}

Denna studies syfte kan delas in i tre områden. Det första området är en kartläggning av förekomsten av entreprenörskapsutbildning som är tillgänglig för studenter vid högre konstnärliga och kreativa utbildningar i Norden. De utbildningsinstitutioner som ingår i studien är högskolor och universitet i de nordiska länderna samt Färöarna.

Det andra området innebär att hitta goda exempel på sådana entreprenörskapsutbildningar och diskutera dessa i jämförelse med det övriga utbudet.

Studiens tredje område består av rekommendationer baserade på resultatet av kartläggningen. Dessa rekommendationer skall användas som grund för KreaNords arbete med att skapa "policies" för entreprenörskap inom högre konstnärlig och kreativ utbildning.

\section{Resultat}

Integrerad entreprenörskapsutbildning förekommer oftare inom utbildningsområdena interaktiva underhållningsprogram, upplevelser och film. Dessa utbildningsområden är alla ganska unga och man kan därför dra slutsatsen att kursplanerna i större utsträckning är anpassade till den verklighet studenterna möter efter avslutade studier.

Studenter på konstnärliga utbildningar blir ofta erbjudna valbara kurser i entreprenörskap. De här kurserna kan vara anpassade till ett specifikt ämne, eller av mer generell karaktär. En potentiell fara med valbara kurser är att studenter som inte uppfattar sig själva som entreprenörer med stor sannolikhet kommer att välja bort dessa kurser. På grund av detta riskerar de att inte få en möjlighet att se fördelarna med att tänka på sig själva och sina idéer utifrån ett entreprenöriellt perspektiv.

Externa entreprenörskapssatsningar utmärks av att de är av hög kvalitet och drivs av individer och organisationer med utmärkta kunskaper inom entreprenörskap. Deltagande i dessa satsningar bygger ofta på att studenterna tävlar om en plats, och kräver att studenten identifierar sig själv som en entreprenör. 


\section{Rekommendationer}

Termen entreprenörskap behöver fortsättningsvis diskuteras och preciseras. I studieplanerna används termen entreprenörskap för att beskriva en mängd olika färdigheter som projektledning, affärsutveckling, innovation med mera. Det är av yttersta vikt att man enas om en gemensam terminologi för att kunna utveckla nya, funktionella "policies".

Idag finns det nästan ingen information om utfallet av de tillgängliga entreprenörskapsutbildningarna och -satsningarna. För att bestämma innehållet i framtida entreprenörskapskurser, behöver en sammanställning och analys göras av utfallet av redan existerande utbildningar.

Konceptet entreprenörskap behöver presenteras och marknadsföras, speciellt gentemot de mer traditionella utbildningsområdena. Om det presenteras på ett sätt som synliggör fördelarna av entreprenörskapsstudier ökar sannolikheten för att de får en plats i utbildningsplanerna.

Innehållet i entreprenörskapsstudier varierar, och en fortsatt diskussion krävs för att enas kring innehållet. Inom vissa utbildningsområden kan en mer generell profil på entreprenörskapskurserna fungera, medan andra behöver en mycket mer specificerad inriktning.

För att utveckla entreprenörskapsutbildningarna och hitta nya samarbetsmöjligheter behövs ett samnordiskt nätverk. Deltagarna i nätverket ska ha goda kunskaper från den akademiska världen och existerande entreprenörskapssatsningar. Syftet med nätverket är att diskutera de frågeställningar och rekommendationer som presenterats ovan, samt att ta del av varandras kunskap och erfarenhet. Genom att genomföra detta kan en analys av "best practice" i metoder göras, som sedan kan fungera som en struktur att bygga entreprenörskapsstudier och entreprenörsskapssatsningar runt. 


\section{Introduktion}

\section{Inledning}

Under de senaste åren har flera av de nordiska länderna arbetat för att främja de kulturella och kreativa näringarna. Satsningarna på sektorn har gett upphov till nya arbetstillfällen, samtidigt som utbildningarna inom området har blivit allt mer populära och vuxit i antal. Trots de politiska satsningarna befinner sig ofta nyutexaminerade studenter från de konstnärliga och kreativa högre utbildningarna i en svår arbetssituation. I Sverige är antalet förvärvsarbetande ofta lägre än bland övriga utbildningsgrupper och andelen som arbetar i yrken som de är överkvalificerade för är större. En SCB-rapport ${ }^{1}$ visar att de konstnärligt utbildade har en väsentligt annorlunda situation på arbetsmarknaden än de flesta andra grupper av utbildade. Andelen förvärvsarbetande är ofta lägre bland de konstnärligt utbildade än bland övriga utbildningsgrupper. De konstnärligt utbildade får dessutom oftare än andra högskoleutbildade jobb på "för låg nivå".

I rapporten illustreras i vilken utsträckning personer med examen inom olika områden arbetar inom samma inriktning som de har studerat. Även om det insamlade materialet är från år 2004 kan det ge en fingervisning om hur situationen ser ut. Nedan ses en jämförelse mellan personer med examen inom konstnärliga respektive naturvetenskapliga ämnen.

${ }^{1}$ Statistiska centralbyrån. Tema: Utbildning. Sambandet mellan utbildning och yrke. En studie om högskoleutbildningar. 2007:1. 


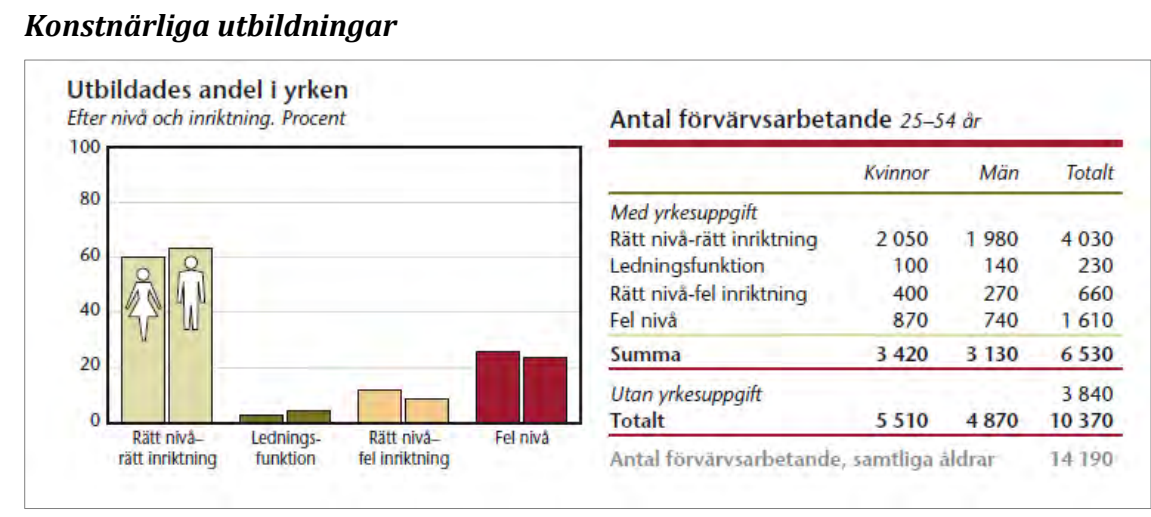

\section{Naturvetenskapliga utbildningar}

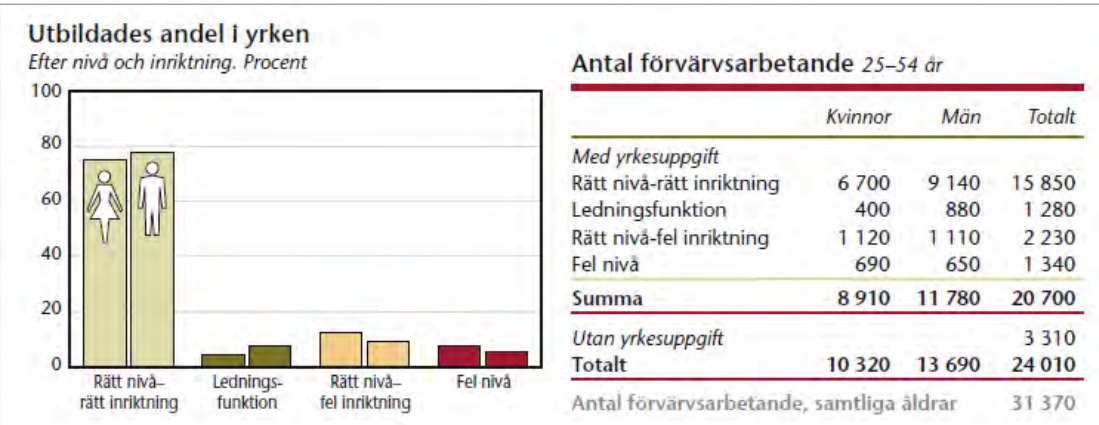

\section{Bakgrund}

De nordiska statsministrarna har efterlyst en gemensam plattform för att utveckla de kulturella och kreativa näringarna inom regionen. I juni 2008 etablerade Nordiska ministerrådet arbetsgruppen KreaNord med uppgift att hitta formerna för ett gemensamt nordiskt policy- och utvecklingsarbete.

KreaNord har identifierat bristen på entreprenörskapsutbildning inom de högre kreativa och konstnärliga utbildningarna som en av de svagheter som påverkar utvecklingen av de kreativa näringarna i regionen. Samtidigt har flera av de nordiska länderna fattat politiska beslut för att införa entreprenörskapsgynnande element i de högre utbildningarna.

För KreaNords fortsatta policy- och utvecklingsarbete behövs en aktuell genomgång av de entreprenöriella inslagen på högre kreativa och konstnärliga utbildningar, exempel på lyckade satsningar och samarbeten med andra aktörer samt politiska beslut och rekommendationer 
av betydelse för utbildningsområdet. Det är den översikten och analysen som denna rapport om entreprenörskap i konstnärliga och kreativa högre utbildningar i Norden ska erbjuda KreaNord.

\section{Målformulering}

En kartläggning görs av utbudet av entreprenörsutbildning inom de högre konstnärliga och kreativa utbildningarna i Norden, vilken ger en överblick av den aktuella situationen.

Relevant forskning och undersökningar på området som uppmärksammats under arbetet presenteras.

Exempel på god integrerad entreprenörsutbildning ges, liksom på andra aktörer, nätverk och satsningar som stärker studenternas förutsättningar för eget företagande.

Rekommendationer för fortsatt utveckling inom området entreprenörskap och högre konstnärliga och kreativa utbildningar, grundade i undersökningsarbetet, presenteras.

\section{Avgränsningar}

För att en tillfredsställande rapport ska kunna sammanställas krävs en klargörande diskussion om de begrepp och mål som är aktuella för projektet.

I studien förstås de önskade möjliga utfallen av entreprenörskapsutbildningarna som att både ge studenter ökade möjligheter att själva försörja sig som egenföretagare efter avslutade studier, och att ge dem ökade möjligheter att förverkliga mer nyskapande idéer i kommersiell verksamhet på ett sätt som inte bara kan försörja den enskilde, utan även många andra.

Frågan om vilken innebörd av begreppet entreprenörskap man väljer kan också vara avhängigt studiernas inriktning. Därför kommer studien även att belysa om man $\mathrm{t}$ ex inom datorspelutvecklingstudier koncentrerar sig mer på den typen av entreprenörskap som kan leda till att arbetstillfällen genereras för fler personer än individen ensam, i förhållande till exempelvis bildkonststudier, där självförsörjningen lätt framstår som primär.

Bolognaprocessen är ett samarbete mellan de europeiska länderna om högre utbildning, med syfte att främja rörlighet, anställningsbarhet och Europas konkurrenskraft på utbildningsområdet. Inom Bolognaprocessen 
definieras anställningsbarhet (employability) som the ability to gain initial employment, to maintain employment, and to be able to move around within the labour market. ${ }^{2}$ I denna rapport väljer vi därför uttryckligen att se eget företagande som ingående i begreppet anställningsbarhet (selfemployment), även om "anställning" på svenska normalt endast innebär ett kontraktsförhållande mellan en arbetsgivare och en arbetstagare, där den senare inte är att betrakta som en "fri agent".

De utbildningsinstanser som ingår är nordiska högskolor och universitet, vilkas verksamhet i någon utsträckning styrs av regering och parlament.

De utbildningar som ingår i kartläggningen ska vara program som leder fram till en högskole-, kandidat-, bachelor-, magister- eller masterexamen. Det innebär att fristående kurser eller vidareutbildning för yrkesverksamma inte ingår i kartläggningen, även om dessa anordnas av en högskola eller universitet.

Alla poäng benämns ECTS, enligt den gemensamma europeiska standarden.

De kreativa och konstnärliga högre utbildningarna som ingår i kartläggningen är utbildningar inom något av följande områden: reklam, arkitektur, konst och antik, konsthantverk, design, designer, mode, film, interaktiva underhållningsdatorprogram, musik, utövande konst, publicering, programvaror, samt tv och radio. Denna avgränsning är alltså medvetet densamma som anges i KreaNords mandat.

Konstnärliga, kulturella och kreativa är tre begrepp som ofta används som synonymer till varandra, men för genomförandet av rapporten kommer benämningen konstnärliga och kreativa högre utbildningar att användas för att ringa in det relevanta området.

De länder och områden som ingår i studien är Danmark, Finland, Island, Norge, Sverige samt Färöarna.

\section{Metod}

Den inledande fasen och huvuddelen av materialinsamlingen har skett genom sökningar på Internet. Vissa organisationer och utbildningsinsatser har sedan direkt kontaktats för djupare information om deras verksamhet. De har också tillfrågats om vilka andra aktörer inom området de känner till.

${ }^{2}$ The official Bologna Process website July 2007-June 2010. 
Tidigare kartläggningar om entreprenörskap inom den högre utbildningen har också använts som utgångspunkt vid insamlandet av material, liksom den rapport som sammanställts i augusti 2010 av Tillväxtverket, rörande situationen hos de svenska kreativa och konstnärliga högre utbildningarna. ${ }^{3}$

Denna iterativa insamling av material via Internet och i uppföljande kontakter med individer i respektive verksamhet har skett tills en "mättnad" har uppnåtts, där relevanta data inte längre tillkommit i en utsträckning som motiverat fortsatt arbete med datainsamlingen. Att mera grundligt kartlägga samtliga utbildningsprogram i de nordiska länderna och att analysera respektive kursplan har alltså inte ingått i uppgiften. Istället har målet med materialinsamlingen varit att dels lyfta fram de mest kända instanserna inom kreativ och konstnärlig utbildning, dels nya utbildningsprogram inom växande områden.

Det insamlade materialet har i omgångar sammanställts och stämts av med referensgruppen.

\section{Metoddiskussion}

Den stora mängden material som finns tillgänglig, och den oundvikliga gallring som det ger upphov till, leder till en risk för att en del intressanta och relevanta satsningar på entreprenörskap kan komma att förbises.

Inom referensgruppen kan inte en heltäckande bild av utbudet förväntas finnas, även om deras granskning ska garantera att de, även ur akademisk synvinkel, mest intressanta aktörerna och satsningarna finns med i det studerade och beskrivna materialet.

\section{Referensgrupp}

För att säkerställa att inga viktiga eller speciellt relevanta entreprenörskapssatsningar faller bort vid insamlandet av material har en referensgrupp med medlemmar från alla nordiska länder samt Färöarna bistått i arbetet med rapporten. Referensgruppens uppgift är också att granska samt ge förslag på de rekommendationer som presenteras i rapporten. Referensgruppen består av: 
- Professor Bengt Johannisson, Ekonomihögskolan, Linnéuniversitetet, Jönköping och Växjö, SE.

- Förste amanuens Donatella Di Paoli, Institutt for kommunikasjon kultur og språk, Handelshøyskolen BI, Oslo, NO.

- Professor Alf Rehn, Företagsekonomi, Handelshögskolan vid Åbo Akademi, Åbo, FI.

- Rektor Christer Windeløv-Lidzélius, KaosPilot Aarhus, DK.

- Dekan Mist Porkelsdóttir, Department of Music, Iceland Academy of the Arts, Reykjavik, IS.

- Project Manager Unn Poulsen, Business Development Dept, Samvit, Torshavn, FO. Ersatt av Manager Sigvør Laksá, Gøta, FO, i oktober 2010 på grund av ändrade arbetsförhållanden.

\section{Entreprenörskap}

En diskussion och definition av begreppet entreprenörskap är också en nödvändig del av vårt arbete. Begreppet entreprenörskap kan betraktas och definieras utifrån olika vinklar beroende på syftet. Inom nationalekonomin har Joseph A. Schumpeter (1883-1950) varit en av de mera tongivande teoretikerna. Enligt Schumpeter är en entreprenör en företagare som kombinerar de befintliga produktionsfaktorerna på ett nytt sätt, och genom detta rubbar marknadens jämvikt och skapar utveckling. ${ }^{4}$

EU-kommissionens expertgrupp för utbildning i entreprenörskap har i sin rapport "Entrepreneurship in higher education, especially within non-business studies" (2008) diskuterat entreprenörskapsutbildningens möjliga innehåll så här: ${ }^{5}$

${ }^{4}$ Wikipedia. http://sv.wikipedia.org/wiki/Joseph_Schumpeter

${ }^{5}$ European Commission. Enterprise and industry directorate-general. Entrepreneurship in higher education, especially within non-business studies, 2008:3. 
"Entrepreneurship education should not be confused with general business and economic studies; its goal is to promote creativity, innovation and selfemployment, and may include the following elements:

- developing personal attributes and skills that form the basis of an entrepreneurial mindset and behaviour (creativity, sense of initiative, risk-taking, autonomy, self-confidence, leadership, team spirit, etc.);

- raising the awareness of students about self-employment and entrepreneurship as possible career options;

- working on concrete enterprise projects and activities;

- providing specific business skills and knowledge of how to start a company and run it successfully."

I EU-kommissionens diskussion kan man isolera två olika innehåll som entreprenörskapsutbildningar kan bestå av - en specifik utbildning i hur man startar och driver ett företag och en bredare utbildning i företagsamhet innefattande utveckling av egenskaper så som kreativitet och risktagande.

Tillväxtverket, en myndighet under det svenska Näringsdepartementet, med ansvar att arbeta för att öka antalet företag och utveckla ett hållbart och konkurrenskraftigt näringsliv i alla delar av landet, definierar entreprenörskap så här: 6

"Entreprenörskap är en dynamisk och social process, där individer, enskilt eller i samarbete, identifierar möjligheter och gör något med dem för att omforma idéer till praktiska och målinriktade aktiviteter i sociala, kulturella eller ekonomiska sammanhang."

Danska "Fonden for Entreprenørskab" har definierat entreprenörskap som: ${ }^{7}$

"Entreprenørskab i undervisningen er et samlende begreb, der indeholder såvel kreativitet som innovation og iværksætteri. Uddannelsernas faglighed er kernen, mens kreativitet, innovation og iværksætteri som bånd snor sig omkring hele uddannelseforløbet o skaber sammenhæng." 
Att hitta en objektiv och gemensam tolkning av begreppet entreprenörskap framstår för oss här som närmast omöjligt och oftast verkar begreppet definieras utifrån avsändarens syfte. Om en liknande tendens kan hittas bland utbildningarna kan detta i sig vara värt att studera närmare.

För denna rapport har vi alltså valt att fastställa att det inom begreppet entreprenörskapsutbildning skall ingå:

- Utbildning med syfte att ge studenterna kunskap om företagandets reella villkor.

- Utbildning med syfte att utveckla studenternas entreprenöriella egenskaper.

\section{Annan relevant forskning}

Danska Fonden for Entreprenørskab har under hösten 2010 publicerat sin rapport "Entreprenørskab fra $\mathrm{ABC}$ til ph.d." ${ }^{8}$ som är en kartläggning av entreprenörskapsinslagen inom hela det danska utbildningssystemet. Rapporten innehåller intressanta siffror som berör andelen studenter som deltagit i de entreprenörskapsgynnande insatser.

Som en del av den svenska regeringens "Handlingsplan för kulturella och kreativa näringar" har Tillväxtverket under år 2010 getts i uppdrag att kartlägga förekomsten av entreprenörskapsutbildning inom de berörda utbildningsområdena i Sverige. Det material som Tillväxtverket presenterat i sin studie har ingått som underlag för denna rapport.

Nordic Innovation Centres rapport "Creative Industries Education in the Nordic countries" 9 har använts som underlag för att ge en bild av utbildningar inom upplevelseindustrin. Nordic Innovation Centre har även publicerat "A Creative Economy Green Paper for the Nordic Region" 10 som innehåller rekommendationer som berör den kreativa industrin på ett mer generellt plan.

${ }^{8}$ Fonden for Entreprenørskab. Entreprenørskab fra ABC til ph.d., 2010.

${ }^{9}$ Nordic Innovation Centre. Creative Industries Education in the Nordic Countries, 2007.

${ }^{10}$ Nordic Innovation Centre. A Creative Economy Green Paper for the Nordic Region, 2007. 
Pilotstudien "Att leva på sin talang - kreatörens behov av entreprenörskap" 11 som genomförts på uppdrag av KK-stiftelsen ger en sammanfattande bild av hur situationen såg ut i Sverige för 5 år sedan och vilka problemställningar som formulerades då.

"Creating Entrepreneurship. Higher Education and the Creative Industries"12 är en rapport som sammanställts av University of Brighton och Nesta (The National Endowment for Science, Technology and the Arts). Den ger en överblick av utbudet av entreprenörskapsutbildning inom kreativa utbildningar i Storbritannien.

11 Gullander et al. Att leva på sin talang - kreatörens behov av entreprenörskap, 2005

12 The Higher Education Academy Art Design Media Subject Centre (Brighton University) och The National Endowment for Science, Technology and the Arts. Creating Entrepreneurship. Higher Education and the Creative Industries, 2007. 



\section{Resultatredovisning}

Alla de nordiska länderna erbjuder högre utbildning på högskola eller universitet. Universiteten utmärks av att man inom dem har rätt att utfärda examina på forskarutbildningsnivå. Utbildningssystemet för de respektive länderna och Färöarna skisseras kort nedan i de kapitel som berör respektive land.

I tabellformat presenteras i det följande exempel på utbildningsinstanser som erbjuder utbildningar inom de olika områdena arkitektur, interaktiva underhållningsprogram, design, formgivning och mode, litteratur och förlagsverksamhet, marknadskommunikation och reklam, media, scenkonst och musik, rörlig bild och foto samt upplevelser.

Entreprenörskapsutbildningarna och andra entreprenörsskapsgynnande insatser presenteras genom att högskole- och universitetsövergripande satsningar åskådliggörs först. Därefter tas utbildningsprogram med entreprenörskapsinnehåll upp under rubriker relaterade till de områden som ingår de konstnärliga och kreativa områdena.

\subsection{Danmark}

Högre utbildning i Danmark delas in i tre kategorier - kort högre utbildning, medellång högre utbildning och lång högre utbildning. De korta högre utbildningarna spänner oftast över två år, men kan även vara längre. De medellånga utbildningarna fokuserar i i regel på särskilda ämnen och varar normalt i 3-4 år. De långa högre utbildningarna varar i 3-6 år. Gemensamt för dessa utbildningar är att de är forskningsbaserade och ger såväl breda ämneskunskaper som specialiserade kunskaper. Bachelorgrad uppnås efter tre års utbildning och efter det kan man läsa vidare i två år, varefter man uppnår en kandidatgrad. 
Den danska regeringen har satsat speciellt på att utveckla den entreprenöriella andan genom hela utbildningssystemet, bl a genom att etablera Fonden for Entreprenørskab. ${ }^{13}$

Fördelningen mellan utbildningsområdena illustreras av diagrammet nedan.

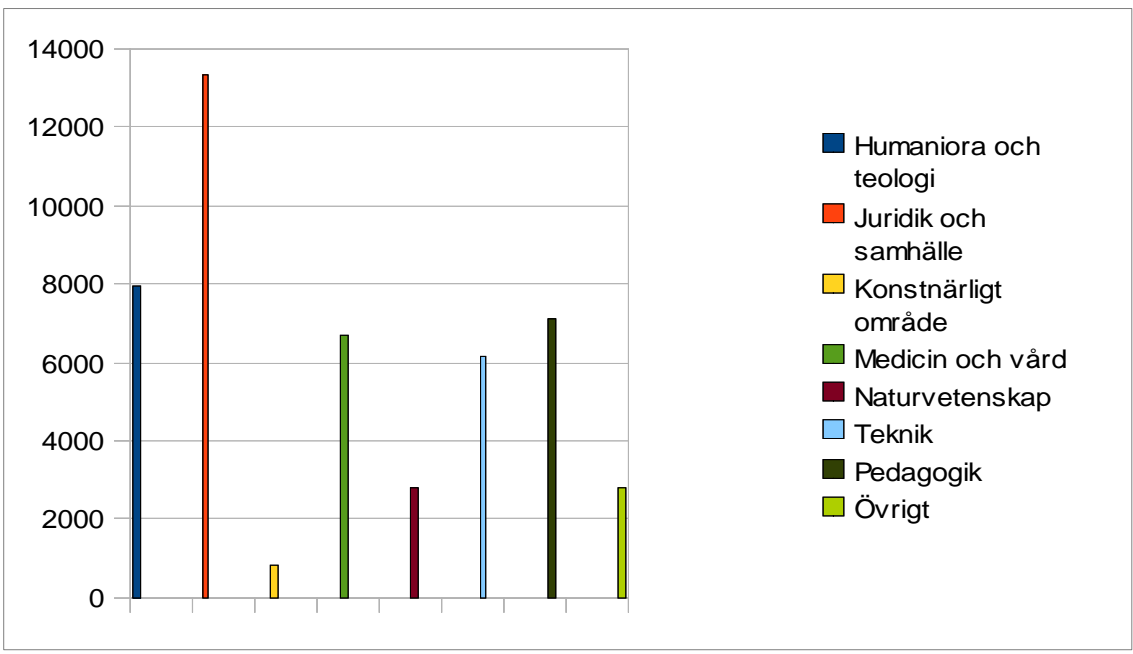

Källa: Danmarks statistik. ${ }^{14}$

\subsubsection{Exempel på utbildningsområden och instanser som erbjuder dessa}

\begin{tabular}{|c|c|}
\hline Ämnesområde & Utbildningsinstanser \\
\hline Arkitektur & $\begin{array}{l}\text { Aalborg universitet } \\
\text { Arkitektskolen Aarhus } \\
\text { Kunstakademiens Arkitektskole }\end{array}$ \\
\hline Interaktiva underhållningsprogram & $\begin{array}{l}\text { Danmarks Tekniske Universitet } \\
\text { IT-universitetet i Köpenhamn } \\
\text { Aalborg Universitet }\end{array}$ \\
\hline Design, formgivning, mode & $\begin{array}{l}\text { Danmarks Tekniske Universitet } \\
\text { Syddansk universitet } \\
\text { Det Fynske Kunstakademi } \\
\text { Det Jyske Kunstakademi } \\
\text { Det Kongelige Danske Kunstakademi } \\
\text { Danmarks Designskole } \\
\text { Designsskolen Kolding }\end{array}$ \\
\hline
\end{tabular}

13 Under november 2010 publicerade Fonden for Entreprenønörskab en kvantitativ kartläggning av alla entreprenörskapssatsningar i hela det danska utbildningssystemet.

${ }^{14}$ Danmarks statistik. 


\begin{tabular}{|c|c|}
\hline Ämnesområde & Utbildningsinstanser \\
\hline Marknadskommunikation, reklam & $\begin{array}{l}\text { Handelshøjskolen Aarhus universitet } \\
\text { Mediehøjskolen }\end{array}$ \\
\hline Media (radio, TV, journalistik) & $\begin{array}{l}\text { Roskilde universitet } \\
\text { Syddansk Universitet } \\
\text { Aarhus universitet } \\
\text { Mediehøjskolen }\end{array}$ \\
\hline Scenkonst, musik & $\begin{array}{l}\text { Rytmisk Musikkonservatorium. Aarhus Universitet } \\
\text { Aalborg Universitet } \\
\text { Københavns universitet } \\
\text { Statens Teaterskole }\end{array}$ \\
\hline Rörlig bild och foto & $\begin{array}{l}\text { Den Danske Filmskole } \\
\text { Københavns universitet }\end{array}$ \\
\hline Upplevelser & Roskilde universitet \\
\hline
\end{tabular}

\subsubsection{Universitets/högskoleövergripande satsningar}

\section{IDEA}

IDEA Entrepreneurship Centre ved Syddansk Universitet grundades och stöddes av Ministeriet för vetenskap mellan 2005-2009, idag administreras verksamheten av Syddanskt Universitet. Kompetenscenter för undervisning i entreprenörskap och nätverksbyggande mellan utbildningar och näringsliv.

\section{CAKI - Center for Anvendt Kunstnerisk Innovation}

På uppdrag av danska Kulturministeriet har Workshopscenen fungerat som en tvärvetenskapligt initiativ för att utveckla existerande och nya försörjningsmöjligheter för studenter vid konstnärliga och kreativa utbildningar. Workshopscenen byter namn till CAKI i början av 2011 och har som syfte att fortsätta utveckla entreprenörskapskunnandet hos studenterna genom att erbjuda kurser, rådgivning och nätverksmöjligheter.

\section{Øresund Entrepreneurship Academy}

Gränsöverskridenade organisation med syfte att öka entreprenörskapsutbildningen på de nio universiteten i Öresundsregionen genom rådgivning och stöd till lärosätena.

\section{Aalborgs universitet}

SEA (Supporting Entrepreneurship): 
En del av IDEA. Inkubatormiljö grundad 2005. Vissa ämnen tillåter ett uppehåll för studenter som deltar i inkubator. Sträcker sig över 6 månader, placerad på institutionerna.

- Workshops med mentorer för alla studenter.

- Rådgivning.

- Löpande kurser i entreprenörskap.

- Möjlighet för studenter att delta i WOFIE, workshop i kreativitet, innovation och affärsutveckling.

\section{Aarhus universitet}

Aarhus Entrepreneurship Centre: Arbetar för att öka entreprenörskapsutbildningarna och entreprenörskapsgynnande utbildningsformer. Studentväxthus.

\section{Arkitektskolen Aarhus}

KarriereVærkstedet: Erbjuder tre olika satsningar för studenterna: ArkIdea (studentväxthus), karriärvägledning (individuell och i form av workshops etc.) och InSpe (studentdriven entreprenörskapsförening som arrangerar workshops, events, exkursioner).

\section{Danmarks designskole}

Samarbete med IDEA.

\section{Designskolen Kolding}

Entreprenörskapsundervisning för alla studenter i samarbete med IDEA.

Laboratorier för studenter där nätverk kan skapas och affärsidéer prövas.

\section{Köpenhamns universitet}

Summer School in Entrepreneurship (7,5 ECTS):

- För studenter med bachelorutbildning.

Studentväxthuset Katalyst:

- Drivhus för studenter vid den humanistiska fakulteten. Erbjuder service, utbildning och workshops.

- Kurser i entreprenörskap erbjuds i samarbete med Øresund Entrepreneurship Academy 
- Next Generation, satsning på företagsamhet, samlad strategisk insats.

\section{Roskilde universitet}

RUCInnovation:

- Kurs i "Entreprenörskap, innovation och kreativitet" (7,5 ECTS) för studenter med bachelorexamen.

- Kurs i "Iværksætteri og innovation" i samarbete med IDEA.

- SHEIK (Studenters Hus før Entreprenørskab, Innovation \& Kreativitet) erbjuder coachning.

- Möjlighet för studenter att delta i WOFIE, workshop i kreativitet, innovation och affärsutveckling.

\section{Danmarks Tekniske Universitet}

- DTU Symbion Innovation, erbjuder experthjälp till studenter.

- "Væksthus", erbjuder kurs "Knowledge based entrepreneurship" (okänt antal ECTS). Även vägledning, samt möjlighet att delta i inkubatorverksamhet.

\section{Syddansk universitet}

- IDEA (International Danish Entrepreneurship Academy).

- WOFIE, workshop för kreativitet, innovation och affärsutveckling.

- IDEA Thursday: evenemang som knyter samman studenter/forskare och företag.

- Business Plan Camp: 24 timmar för att kickstarta företag.

- Tool Training.

- IDEA House: studentdrivhus.

\subsubsection{Inslag av entreprenörskap inom utbildningsprogrammen}

Interaktiva underhållningsprogram, programvaror Danmarks Tekniske Universitet:

- Kandidatutbildning i "Digitala Medieteknologier" (120 ECTS).

- Valbar kurs "Verksamhetsstart" (5 ECTS) erbjuds. 


\section{IT-universitetet i Köpenhamn:}

- Bachelorutbildning i "Digitala medier och design" (180 ECTS).

- Kursen "Innovation og iværksætteri" (5 ECTS) ingår.

- Kandidatutbildning i "Digitala medier och design" (120 ECTS).

- Kursen "Innovation, konceptutveckling och projektstyrning" (7,5 ECTS) ingår.

\section{Design, formgivning}

Danmarks Tekniske Universitet:

- Kandidatutbildning i "Design och Innovation" (120 ECTS).

- Valbar kurs "Verksamhetsstart" (5 ECTS) erbjuds.

\section{Scenkonst}

Statens Teaterskole: Skolen för Moderne Dans som är en del av Statens Teaterskole erbjuder en vidareutbildning som omfattar 60 timmar, kallad "Danseren som entreprenør". Utbildningen ger bl a kunskaper i administration, ledning och kommunikation.

\section{Musik}

Rytmisk Musikkonservatorium:

- Bachelorutbildning i "Music Management" (180 ECTS).

- Flera entreprenörsgynnande kurser ingår, bl a i ekonomi, juridik, innovation och företagsstart (sammanlagt 70 ECTS).

\section{Rörlig bild och film}

Den Danske Filmskole:

- Utbildning "Filmproducer" (4 år).

- Ingår utbildning i ekonomi, juridik, finansiering etc.

\section{Upplevelser}

Roskilde universitet: Master i Oplevelseledelse (60 ECTS) är en påbyggnadsutbildning som innehåller kurser som samhälle och marknad, upplevelseproduktion och företagande. I delen om företagande ingår studier i bland annat personalfrågor, innovation och företagsstart.

Copenhagen Business School: Master of Social Science in Management of Creative Business Processes (60 ECTS) är en påbyggnadsutbildning 
med syfte att applicera ekonomivetenskapen på den kreativa industrin. Kursen ger studenterna färdigheter inom områden som den kreativa processen, juridik och personalfrågor - allt anpassat till omständigheterna inom den kreativa industrin.

\subsection{Finland}

I Finland finns sammanlagt 21 universitet och 31 yrkeshögskolor. På universiteten kan studenterna läsa en kandidatexamen om 3 år (180 ECTS) och därefter komplettera med en magisterexamen om 2 år (120 ECTS).

Yrkeshögskolorna erbjuder utbildningsprogram som leder fram till en lägre yrkeshögskoleexamen. Dessa program är mellan 3 och 4 år långa. En student som avslutat en lägre yrkeshögskoleexamen samt varit yrkesverksam minst 3 år kan komplettera sin utbildning med en högre yrkeshögskoleexamen om 1-1,5 år.

År 2009 uppgick antalet studenter vid finländska yrkeshögskolor och universitet till ca 300 000. Fördelningen mellan utbildningsområdena illustreras nedan.

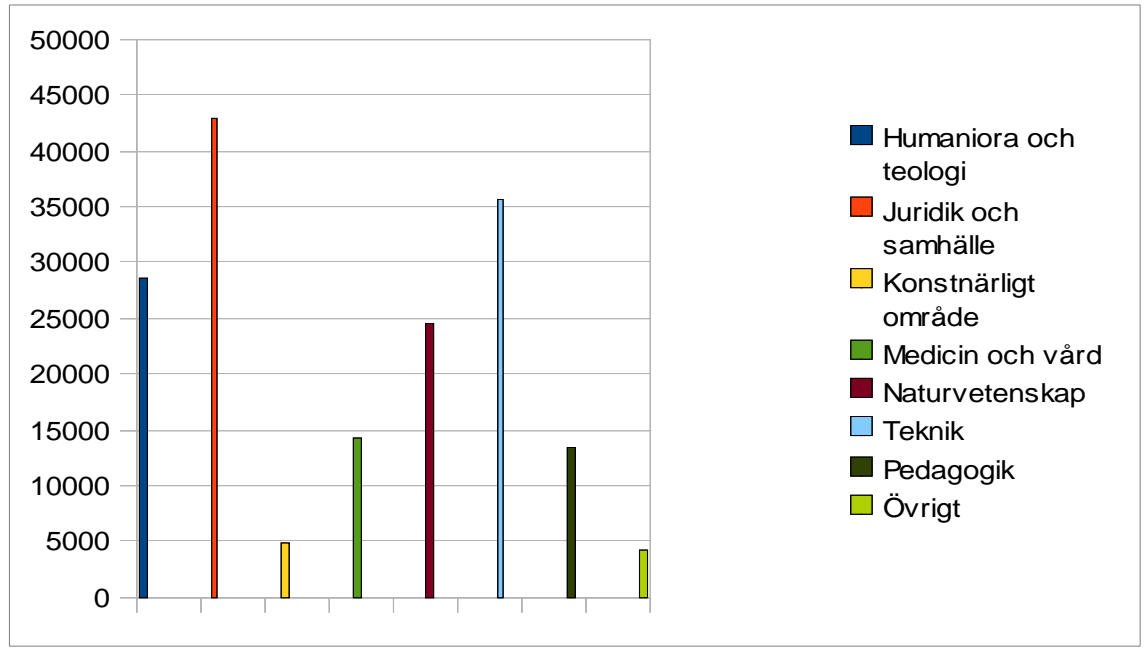

Källa: Tilastokeskus. ${ }^{15}$

15 Tilastokeskus 


\subsubsection{Exempel på utbildningsområden och instanser som erbjuder dessa}

\begin{tabular}{|c|c|}
\hline Ämnesområde & Utbildningsinstanser \\
\hline \multirow[t]{3}{*}{ Arkitektur } & Tekniska högskolan (Aalto-universitetet) \\
\hline & Uleåborgs universitet \\
\hline & Tammerfors tekniska universitet \\
\hline \multirow[t]{3}{*}{ Interaktiva underhållningsprogram } & Lapplands universitet \\
\hline & Kajaana yrkeshögskola \\
\hline & Norra Karelens yrkeshögskola \\
\hline \multirow[t]{7}{*}{ Design, formgivning, mode } & Yrkeshögskolan Novia \\
\hline & Konstindustriella högskolan (Aalto-universitetet) \\
\hline & Bildkonstakademin \\
\hline & Lapplands universitet \\
\hline & Lahtis yrkeshögskola \\
\hline & Åbo yrkeshögskola \\
\hline & Yrkeshögskolan Metropolia \\
\hline \multirow[t]{6}{*}{ Media (radio, TV, journalistik) } & Tammerfors universitet \\
\hline & Svenska social- och kommunalhögskolan \\
\hline & Helsingfors universitet \\
\hline & Vasa universitet \\
\hline & Jyväskylä universitet \\
\hline & Lahtis yrkeshögskola \\
\hline \multirow[t]{6}{*}{ Scenkonst, musik } & Yrkeshögskolan i Jyväskylä \\
\hline & Konstindustriella högskolan (Aalto-universitetet) \\
\hline & Teaterhögskolan \\
\hline & Tammerfors universitet \\
\hline & Sibelius-Akademin \\
\hline & Yrkeshögskolan Metropolia \\
\hline \multirow[t]{3}{*}{ Rörlig bild och foto } & Konstindustriella högskolan (Aalto-universitetet) \\
\hline & Lahtis yrkeshögskola \\
\hline & Åbo yrkeshögskola \\
\hline Upplevelser & Yrkeshögskolan Novia \\
\hline
\end{tabular}

\subsubsection{Universitets/högskoleövergripande satsningar}

\section{Boost Turku}

Studentdriven organisation som samarbetar med universiteten i Åbo. Boost Turkus mål är att öka intresset för entreprenörskap bland studenterna och att skapa nya nätverk och möjligheter. Det görs $t$ ex genom träffar, workshops och pitchningar.

\section{Aalto Entrepreneurship Society}

Målet med Aalto Entrepreneurship Society är att hjälpa studenter och forskare att utveckla idéer, skapa arbetsgrupper och starta nya företag. Organisationen, som är studentdriven, arrangerar möten med coacher, sammanför personer som kan dra nytta av varandra samt ordnar träningsläger för att utveckla entreprenörskap. För studenter vid Aalto-universitetet. 


\section{Aalto-universitetet}

- Samarbete mellan Handelshögskolan, Tekniska högskolan och Konstindustriella högskolan.

- Kreativa utvecklings- och innovationssatsningar.

- Gemensamma kurser som erbjuds på Aalto-universitetet:

o "Aaltoliike project" (15 ECTS), produktprocessen alla delar, affärsmöjligheter, marknadsföring. Erbjuds mastersstudenter inom ämnena Design, Marknadsföring samt Produktionsdesign och -teknik.

o "Creativity and Innovation 2.0" (2 ECTS), workshop för masterstudenter.

o "MediaBizLab" (20-25 ECTS), kurser i design, teknik och affärsutveckling.

\section{HMEA (Helsinki Metropolitan Entrepreneurship Academy)}

- Entreprenörsprogram öppet för studenter vid högre utbildning, deltagandet kan i vissa fall ge studiepoäng.

- Erbjuder återkommande föreläsningar under namnet "Entrepreneurship Tuesday".

- Workshops kring ämnen som affärsutveckling, marknadsföring, pitchning etc.

- I samarbete med universitetet i Cambridge arrangerar HMEA boot camps om entreprenörskap.

\section{Innoplaza}

Modul i entreprenörskap (10 ECTS) som studenter från yrkeshögskolor i huvudstadsregionen kan delta i. I moduler ingår undervisning i innovation, projektledning, marknadsförening, företagsekonomi etc. Årligen väljs 40 studenter ut, baserat på intervjuer, som får delta i Innoplazas utbildning.

\section{Yrkeshögskolan Arcada}

Har etablerat fokusområdet Innovationskraft som ska uppmuntra studenterna att utveckla affärsidéer genom t ex tillgång till laboratorier och programvara. Genom satsningen Innobox erbjuds studenterna rådgivning kring affärsutveckling och innovation. 


\subsubsection{Inslag av entreprenörskap inom utbildningsprogrammen}

\section{Design, formgivning}

Yrkeshögskolan Novia:

- Utbildning "Estenom" (210 ECTS).

- Kurser i entreprenörskap ingår.

Aalto-universitetet:

- Masterutbildning i "International Design Business Management" (120 ECTS).

- Utbildar studenterna i affärsutveckling.

Lahtis yrkeshögskola:

- Utbildning i Textil- och beklädnadsteknik (240 ECTS).

- Ett utbildningsblock om 12 ECTS ingår, med fokus på företagande, marknadsföring etc.

\section{Musik}

Sibelius Akademin: Masterprogrammet Arts Management lär ut ämnen som som företagande, organisation och affärsutveckling parallellt med konstämnen.

Yrkeshögskolan i Jyväskylä: Studenter som har en bachelorexamen inom musik från Yrkeshögskolan i Jyväskylä kan delta i masterutbildningen New Audiences and Innovative Practice (60 ECTS) som är ett samarbete mellan nämnda högskola, Prince Claus Conservatoire in Groningen (NL), Royal Conservatoire in The Hague (NL), Guildhall School of Music \& Drama (UK) och Iceland Academy of the Arts (IS). Genom utbildningen lär sig studenterna att utveckla och leda projekt både inom musikscenen, men också projekt som berör andra områden.

\section{Rörlig bild och film}

Åbo Yrkeshögskola: Utbildningsprogrammet Animation (240 ECTS) innehåller en obligatorisk kurs i företagande om 5 ECTS. Under kursen behandlas bl a grundläggande företagskunskap, marknadsföring och upphovsrätt.

\section{Upplevelser}

Yrkeshögskolan Novia: 
- Magisterutbildning i "Kulturproducentskap" (240 ECTS).

- Kurser i entreprenörskap ingår.

\subsection{Island}

Island har idag 7 universitet och högskolor som erbjuder bachelorutbildningar i olika ämnen, som kan följas av en mastersutbildning inom en del ämnen. Háskóli Íslands (Islands universitet) ger även yrkesinriktade kandidatutbildningar.

Antalet studenter vid isländska universitet och högskolor uppgick hösten 2008 till 16944 och ämnesfördelningen illustreras av bilden nedan.

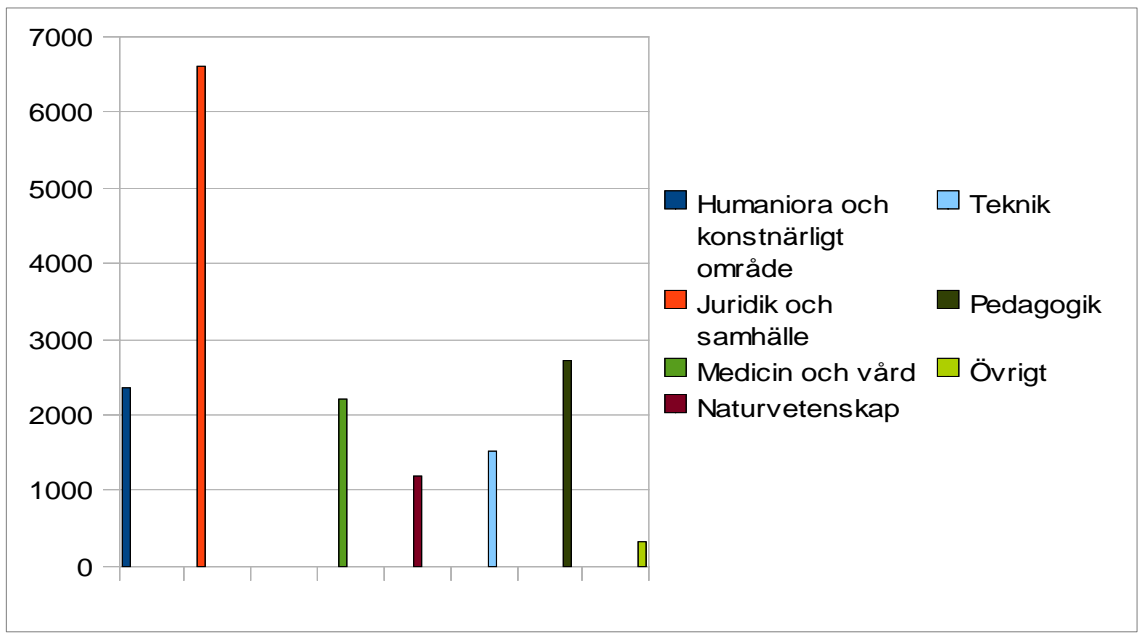

Källa: Hagstofa Íslands. ${ }^{16}$

\subsubsection{Exempel på utbildningsområden och instanser som erbjuder dessa}

\begin{tabular}{ll} 
Ämnesområde & Utbildningsinstanser \\
Arkitektur & The Iceland Academy of the Arts \\
Interaktiva underhållningsprogram & Reykjavik University \\
Design, formgivning, mode & The Iceland Academy of the Arts \\
Media (radio, TV, journalistik) & University of Akureyri \\
Scenkonst, musik & The Iceland Academy of the Arts \\
Upplevelser & Bifröst University \\
\hline
\end{tabular}

${ }^{16}$ Hagstofa Íslands. 


\subsubsection{Universitets/högskoleövergripande satsningar}

\section{Klak}

Innovationscenter som erbjuder sina tjänster till såväl etablerade näringsidkare som studenter. Studenter kan delta i "Business Accelerator", ett utbildningsblock som spänner över åtta veckor av vilka deltagarna kan välja att delta i alla eller plocka ut de mest användbara delarna. Förutom kurser i entreprenörskap erbjuder "Business Accelerator" även konsultation och träning.

\section{Keilir School of Creative Industries}

Inom området "School of Creative Industries" kopplas konst och entreprenörskap samman. Syftet är att utbilda studenterna att ta sina idéer vidare och utveckla dem i kommersiell riktning. Utbildningen ges i samarbete med Háskóla Íslands (Islands universitet) tekniska och naturvetenskapliga fakultet och Innovation Center of Iceland.

\section{Innovit}

Studenter som avslutat sina studier vid Islands universitet, Universitetet i Reykjavik och Universitetet i Bifröst kan delta Innovits verksamhet upp till fem år efter att de lämnat universiteten. Innovit är ett självständigt center för innovation och entreprenörskap som erbjuder gratis lokaler, konsultation, föreläsningar, kurser, praktikplatser under sommaren och en årlig entreprenörstävling.

\subsubsection{Inslag av entreprenörskap inom utbildningsprogrammen}

\section{Musik}

Studenter som har en bachelorexamen inom musik från Iceland Academy of the Arts kan delta i masterutbildningen New Audiences and Innovative Practice (60 ECTS) som är ett samarbete mellan nämnda universitet, Prince Claus Conservatoire in Groningen (NL), Royal Conservatoire in The Hague (NL), Guildhall School of Music \& Drama (UK) och Yrkeshögskolan i Jyväskylä (FI). Genom utbildningen lär sig studenterna att utveckla och leda projekt både inom musikscenen, men också projekt som berör andra områden.

\section{Upplevelser}

Bifröst University erbjuder en masterutbildning i Cultural Management (120 ECTS). Programmets syfte är att utbilda studenterna i bl a projektledning och verksamhetstyrning inom kreativa och kulturella näringar. 


\subsection{Norge}

I Norge finns 7 universitet och 22 högskolor, samt 6 vetenskapliga högskolor samt två konsthögskolor. Förutom det finns även en rad privata högre utbildningsinstitutioner. Alla dessa lärosäten regleras av en gemensam lag om universitet och högskolor.

Examensstrukturen följer följande struktur:

- Kandidatexamen 120 ECTS.

- Bachelorexamen 180 ECTS.

- Masterexamen 120 ECTS.

- Yrkesinriktad högskoleexamen 240-360 ECTS.

År 2008/2009 fullföljde 34119 studenter en lägre eller högre högskole/universitetsexamen. Fördelningen mellan utbildningsområdena illustreras av diagrammet nedan.

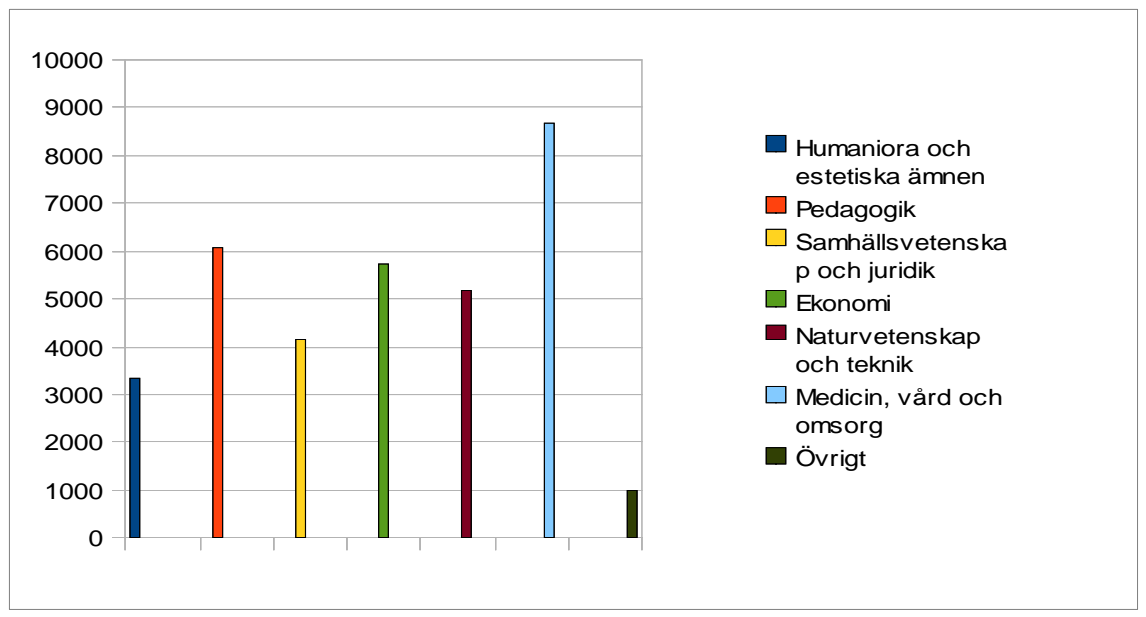

Källa: Statistisk Sentralbyrå. ${ }^{17}$

${ }^{17}$ Statistisk Sentralbyrå 


\subsubsection{Exempel på utbildningsområden och instanser som erbjuder dessa}

\begin{tabular}{|c|c|}
\hline Ämnesområde & Utbildningsinstanser \\
\hline \multirow[t]{2}{*}{ Arkitektur } & Arkitektur- og designhøjskolen i Oslo \\
\hline & Norges teknisk-naturvitenskapelige universitet \\
\hline \multirow[t]{4}{*}{ Interaktiva underhållningsprogram } & Universitetet i Agder \\
\hline & Høgskolen i $\emptyset$ stvold \\
\hline & Høgskolen i Nord-Trøndelag \\
\hline & Høgskolen i Hedmark \\
\hline \multirow[t]{8}{*}{ Design, formgivning, mode } & Høgskolen i $\varnothing$ stvold \\
\hline & Universitetet i Agder \\
\hline & Kunsthøgskolen i Oslo \\
\hline & Høgskolen i Akershus \\
\hline & Høgskolen i Oslo \\
\hline & Høgskolen i Telemark \\
\hline & Høgskolen i Vestfold \\
\hline & Kunstakademiet \\
\hline \multirow[t]{2}{*}{ Litteratur, förlagsverksamhet } & Universitetet i Oslo \\
\hline & Handelshøyskolen BI \\
\hline Marknadskommunikation, reklam & Westerdahl Markedh $\varnothing$ yskolen \\
\hline \multirow[t]{4}{*}{ Media (radio, TV, journalistik) } & Universitetet i Stavanger \\
\hline & Høgskolen i Bod $\varnothing$ \\
\hline & Høgskolen i Oslo \\
\hline & Høgskolen i Lillehammer \\
\hline \multirow[t]{8}{*}{ Scenkonst, musik } & Universitetet i Agder \\
\hline & Høgskolen i Hedmark \\
\hline & Kunsthøgskolen i Oslo \\
\hline & Universitetet i Stavanger \\
\hline & Høgskolen i Oslo \\
\hline & Høgskolen i $\varnothing$ stfold \\
\hline & Kunstakademiet \\
\hline & Handelshøyskolen BI \\
\hline \multirow[t]{6}{*}{ Rörlig bild och foto } & Høgskolen i Lillehammer \\
\hline & Høgskulen i Volda \\
\hline & Norges teknisk-naturvitenskapelige universitet \\
\hline & Universitetet i Bergen \\
\hline & Universitetet i Stavanger \\
\hline & Høgskolen i Oslo \\
\hline \multirow[t]{7}{*}{ Upplevelser } & Universitetet i Agder \\
\hline & Handelshøyskolen BI \\
\hline & Høgskolen i Harstad \\
\hline & Høgskolen i Lillehammer \\
\hline & Høgskolen i Telemark \\
\hline & Høgskolen i Østvold \\
\hline & Høgskolen i Hedmark \\
\hline
\end{tabular}




\subsubsection{Universitets/högskoleövergripande satsningar}

\section{Handelshøyskolen BI}

Bachelorutbildning i Entreprenörskap (180 ECTS) kan kombineras med ämnen som förlagsverksamhet, scenkonst, musik, film, museiverksamhet och galleriverksamhet. Utbildningen i entreprenörskap ger studenterna de verktyg de behöver för att starta en egen verksamhet, men också hur verksamheten kan utvecklas och vilken riktning den kan ta.

Bachelor i kultur og ledelse (180 ECTS) fokuserar på kulturbranscherna som film, musik, litteratur, förlagsverksamhet, visuell konst, museiverksamhet och scenkonst. Ämnen som branschkultur, värdekedjor, kulturpolitik och affärsmodeller behandlas i utbildningen.

\section{Universitetet i Oslo}

Entreprenörskap: Kurs (10 ECTS) öppen för alla studenter.

Gründerskolen (30 ECTS): Bachelorgrad krävs, motivation och personlighet viktigt.

\section{Universitetet i Bergen}

Nyskabingsparken Inkubator: För nyutexaminerade studenter.

Gründerskolen (30 ECTS): Bachelorgrad krävs, motivation och personlighet viktigt.

\section{Universitetet i Stavanger}

Senter for entreprenørskap:

- Studentinkubator.

- Kurs "Studentbedrift" (20 ECTS) för studenter på bachelorprogram.

Gründerskolen (30 ECTS): Bachelorgrad krävs, motivation och personlighet viktigt.

\section{Arkitektur- og designhøgskolen i Oslo}

Gründerskolen (30 ECTS): Bachelorgrad krävs, motivation och personlighet viktigt.

\section{Norges teknisk-naturvitenskapelige universitet (NTNU)}

Resurscentrum i NTNU:s regi tillgängligt för studenterna.

Innovasjonssenter Gløshaugen: Erbjuder lokaler, mötesrum, professionell hjälp. 
NTNU Senter før entreprenørskap: Erbjuder kurser i företagande etc. Främsta fokus på studenter inom ämnena "Industriell ekonomi" och "Teknologiledning", vissa kurser är dock tillgängliga för alla studenter.

\section{Kunsthøgskolen i Bergen}

Bergen Designinkubator

\section{Høgskolen i Buskerud}

SeIE - Hibus senter for Innovasjon og Entreprenørskap: Arrangerar kurs för näringsetablerare och företagsutvecklare.

\subsubsection{Inslag av entreprenörskap inom utbildningsprogrammen}

Interaktiva underhållningsprogram, programvaror

Universitetet i Agder:

- Bachelorprogram i Multimedieteknologi och -design (180 ECTS).

o Under 3:e året ingår kursen "Bedriftsetablering" (5 ECTS) i utbildningen.

Høgskolen i Østvold:

- Bachelorprogram i"Digital medieproduktion" (180 ECTS).

o Valbar kurs "Marknadsföring och företagsstrategi" (10 ECTS) kan ingå i utbildningen.

Høgskolen i Nord-Trøndelag:

- Bachelorprogram i "Multimediadesign" (180 ECTS).

o Kurs "Utveckling av kreativa näringar" ingår.

- Bachelorprogram i "Spel och upplevelseteknologi" (180 ECTS)

o Kurs "Utveckling av kreativa näringar" ingår.

\section{Design, formgivning}

Høgskolen i Østvold:

- Bachelorprogram i "Indutriell design" (180 ECTS).

o Valbar kurs "Ekonomi" (10 ECTS) kan ingå i utbildningen. 
Universitetet i Agder:

- Bachelorprogram i "Konstämnen" (180 ECTS).

o Kurs i entreprenörskap ingår (10 ECTS).

Kunsthøgskolen i Oslo:

- Masterprogram i "Konstfack" (120 ECTS).

o Kurs i "Förmedling och etablering" (12 ECTS) ingår.

- Bachelorprogram i "Bildkonst" (180 ECTS).

o Kurs i "Professionalisering" (9 ECTS) ingår. Ger information om stöd, stipendier, skatteregler etc.

Høgskolen i Akershus:

- Bachelorprogram i "Produktdesign" (180 ECTS).

o Kursen "Estetik och produktion/Samhälle, marknad och näring" (20 ECTS) ingår.

- Masterprogram i "Produktdesign" (120 ECTS).

o Kursen "Teknikförståelse och produktutveckling" (10 ECTS) ingår.

Høgskolen i Oslo:

- Bachelorprogram i "Konst och design" (180 ECTS).

o Under tredje året ingår gemensamma kurser om entreprenörskap och företagande om sammanlagt 20 ECTS till alla studenter på avdelningen för estetiska ämnen.

Høgskolen i Telemark:

- Bachelorprogram i "Visuella konstämnen och design" (180 ECTS).

o Kursen "Studentbedrift" (20 ECTS) ingår. Ger kunskap om entreprenörskap och praktiska kunskaper för näringsidkare.

Høgskolen i Vestfold:

- Bachelorprogram i "Produktdesign" (180 ECTS).

o Kursen "Konceptutveckling" (10 ECTS) ingår. 


\section{Musik}

Universitetet i Agder:

- Bachelorprogram i musik (180 ECTS).

o Kurs i entreprenörskap ingår (10 ECTS).

Høgskolen i Hedmark:

- Bachelorprogram i "Music Management" (180 ECTS).

o Bachelorprogram i "Musikproduktion" (180 ECTS).

o Utbildning i företagande ingår, "Kreativ förrättningsstrategi" (15 ECTS).

\section{Rörlig bild och film}

Høgskolen i Lillehammer:

- Bachelorprogram i "Produktions- och projektledning" med inriktning film (180 ECTS).

o Innehåller kurser i ekonomi, juridik etc.

\section{Upplevelser}

Universitetet i Agder:

- Bachelorprogram i Upplevelsebaserat resande (180 ECTS).

o Entreprenörskapstudier ingår i utbildningen.

BI Handelshøyskolen:

- Bachelorprogram i "Kultur og ledelse" (180 ECTS).

o Fokus i utbildningen ligger på ekonomi och marknadsföring.

- Masterprogram i "Innovation and Entrepreneurship" (120 ECTS)

o För studenter med bachelorexamen från rese och turism- samt informatikutbildningar.

Høgskolen i Harstad:

- Bachelorprogram i "Reseliv och upplevelseproduktion" (180 ECTS).

o Kursen "Innovation and Entrepreneurship in Tourism" ingår (10 ECTS). 
Høgskolen i Lillehammer:

- Bachelorprogram i "Kulturprojektledning" (180 ECTS).

o Kurs i marknadsföring och projektledning ingår (5 ECTS).

- Masterprogram i "Innovation och näringsutveckling" (120 ECTS).

o Kan sökas efter genomgången bachelorutbildning inom olika ämnesområden.

Høgskolen i Telemark:

- Bachelorprogram i "Kultur - arrangemang, förmedling och förvaltning" (180 ECTS).

o Erbjuds även i komprimerad form om 60 ECTS för studenter med bachelorexamen i lämpliga ämnen.

- Påbyggnadsutbildning i "Innovation och entreprenörskap" (60 ECTS).

o För studenter med minst 2 års högre utbildning i lämpliga ämnen.

Høgskolen i Østvold:

- Bachelorprogram i "Innovation och projektledning" (180 ECTS).

Høgskolen i Hedmark:

- Bachelorprogram i "Sport \& Event Management" (180 ECTS).

o Kursen "Kreativ förrättningsstrategi" (10 ECTS) ingår.

\subsection{Sverige}

Den svenska staten är ansvarig för den verksamhet som bedrivs på högskoleområdet. I Sverige finns 14 statliga universitet och 22 statliga högskolor. Förutom dem finns även tre lärosäten med enskild huvudman Chalmers tekniska högskola, Handelshögskolan i Stockholm och Högskolan i Jönköping.

Examina på högskole- och universitetsnivå skiljer sig något mellan de olika lärosätena, och de examina som erbjuds är: 
- Grundnivå:

o Högskoleexamen 120 ECTS.

o Kandidatexamen 180 ECTS.

- Avancerad nivå:

o Magisterexamen 60 ECTS.

o Mastersexamen 120 ECTS.

- Forskarnivå:

o Licentiatexamen 120 ECTS.

o Doktorsexamen 240 ECTS.

Antal heltidsstudenter höstterminen 2009 i Sverige, fördelat enligt ämnesområden

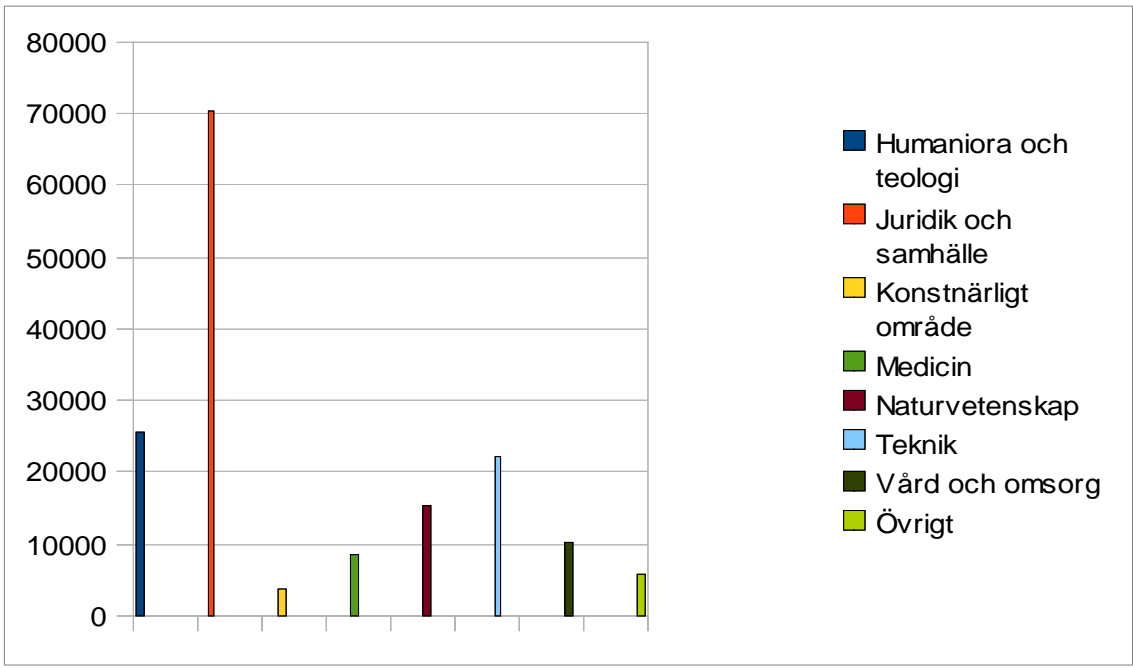

Källa: Högskoleverket. ${ }^{18}$

18 Högskoleverket. 


\subsubsection{Exempel på utbildningsområden och instanser som erbjuder dessa}

\begin{tabular}{|c|c|}
\hline Ämnesområde & Utbildningsinstanser \\
\hline Arkitektur & $\begin{array}{l}\text { Kungliga Tekniska Högskolan } \\
\text { Chalmers Tekniska Högskola } \\
\text { Lunds Tekniska Högskola } \\
\text { Konstfack } \\
\text { Högskolan för Design och Konsthantverk } \\
\text { Umeå universitet } \\
\text { Sveriges lantbruksuniversitet } \\
\text { Blekinge Tekniska Högskola }\end{array}$ \\
\hline Interaktiva underhållningsprogram & $\begin{array}{l}\text { Högskolan i Skövde } \\
\text { Blekinge Tekniska Högskola } \\
\text { Högskolan Väst } \\
\text { Malmö Högskola } \\
\text { Mälardalens högskola } \\
\text { Luleå Tekniska Universitet } \\
\text { Stockholms universitet } \\
\text { Högskolan på Gotland } \\
\text { Örebro universitet }\end{array}$ \\
\hline Design, formgivning, mode & $\begin{array}{l}\text { Högskolan i Väst } \\
\text { Linnéuniversitetet } \\
\text { Linköpings universitet } \\
\text { Göteborgs universitet } \\
\text { Konstfack } \\
\text { Umeå universitet } \\
\text { Högskolan i Borås }\end{array}$ \\
\hline Litteratur, förlagsverksamhet & Göteborgs universitet \\
\hline Marknadskommunikation, reklam & $\begin{array}{l}\text { Stockholms universitet } \\
\text { Linnéuniversitet } \\
\text { Högskolan Dalarna } \\
\text { Örebro universitet }\end{array}$ \\
\hline Media (radio, TV, journalistik) & $\begin{array}{l}\text { Högskolan i Väst } \\
\text { Högskolan i Jönköping } \\
\text { Mittuniversitetet } \\
\text { Örebro universitet } \\
\text { Luleå tekniska universitet } \\
\text { Södertörns högskola } \\
\text { Göteborgs universitet } \\
\text { Linnéuniversitetet } \\
\text { Stockholms universitet } \\
\text { Lunds universitet }\end{array}$ \\
\hline Scenkonst, musik & $\begin{array}{l}\text { Göteborgs universitet } \\
\text { Kungliga Musikhögskolan } \\
\text { Lunds universitet } \\
\text { Högskolan Dalarna } \\
\text { Örebro universitet } \\
\text { Dramatiska Institutet } \\
\text { Dans och Cirkushögskolan }\end{array}$ \\
\hline Rörlig bild och foto & $\begin{array}{l}\text { Högskolan Väst } \\
\text { Göteborgs universitet } \\
\text { Örebro universitet } \\
\text { Lunds universitet } \\
\text { Dramatiska Instituttet }\end{array}$ \\
\hline
\end{tabular}




$\begin{array}{ll}\text { Ämnesområde } & \text { Utbildningsinstanser } \\ \text { Upplevelser } & \text { Luleå tekniska universitet } \\ & \text { Örebro universitet } \\ & \text { Högskolan i Borås } \\ \text { Linnéuniversitetet }\end{array}$

\subsubsection{Universitets/högskoleövergripande satsningar}

\section{Konstfack}

Obligatorisk kurs "Professionell utveckling" för alla kandidatstudenter. Kursen innehåller en veckas undervisning i entreprenörskap med fokus på eget företagande, och en vecka som handlar om att presentera och kommunicera sin kompetens och/eller sina verk.

\section{Stockholm School of Entrepreneurship}

Karolinska Institutet, Kungliga Tekniska Högskolan, Handelshögskolan i Stockholm, Konstfack och Stockholms universitet ingår tillsammans i Stockholm School of entrepreneurship som ett komplement till de utbildningar medlemsskolorna kan erbjuda. Studenter vid medlemsskolorna kan läsa kurser som:

- Ideation - Creating a Business Idea.

- Design and Innovation.

Stockholm School of Entrepreneurship erbjuder även program, t ex Entrepreneurship and Innovation Management (60 ECTS).

\section{Göteborgs universitet}

Vid konstnärliga fakulteten ges sedan 2009 en sommarkurs "Konsten att leva på sin konst" som är öppen för alla studenter som studerar eller har studerat vid en konstnärlig högskola. Kursen omfattar 15 ECTS och ger studenterna verktyg för att lyckas med en yrkeskarriär inom det konstnärliga området.

\section{Högskolan för design och konsthantverk vid Göteborgs universitet}

I samarbete med Handelshögskolan i Göteborg har HDK startat verksamheten "Business \& Design Lab". Masterutbildningen "Business \& Design" erbjuds studenter med en bachelorexamen i design eller ekonomi. Dessutom ges inom ramen för "Business \& Design Lab" fristående kurser som t ex:

- Design, redovisning och avtalsrätt 6 ECTS. 
- Företagsekonomi och management för icke-ekonomer 7,5 ECTS.

- Design och marknadsföring 6 ECTS.

\section{Högskolan i Skövde}

För studenter som har minst 150 ECTS erbjuds "Entreprenörsutbildningen" (60 ECTS) i samarbete med Gothia Science Park. Målet är att studenterna redan under utbildningen ska kunna starta ett fungerande och lönsamt företag.

\section{Lunds universitet}

Projektledning och entreprenörskap för humanister (15 ECTS) erbjuds studenter i slutskedet av sina studier vid humanistiska fakulteten. Kursen vill visa hur idéer kan utvecklas till affärsmöjligheter.

\section{Södertörns högskola}

Kursen "Kultur \& entreprenörskap" (15 ECTS) fungerar som ett komplement till de estetiska utbildningarna vid universitet och högskolor. Kursen behandlar bl a entreprenörskap, företagande och omvärldsorientering.

\section{Blekinge Tekniska Högskola}

BTH Innovations Business Lab erbjuder poänggivande kurser, rådgivning, föreläsningar och innovationstävlingar för studenter, forskare och lärare med affärsidéer.

\subsubsection{Inslag av entreprenörskap inom utbildningsprogrammen}

\section{Interaktiva underhållningsprogram}

Högskolan i Skövde: Masterprogram "Serious Games" (60 ECTS) innehåller kurserna Affärsplanering (7,5 ECTS) och Entreprenörskap - villkor och särprägel (7,5 ECTS) vilka ger studenterna de kunskaper som behövs för att verka som entreprenörer på området.

Högskolan Väst: Bachelorutbildningen i 3D-animation och visualisering (180 ECTS) innehåller en kurs i entreprenörskap om 7,5 ECTS. Kursen ska bidra till att studenterna visar "förståelse för ett entreprenöriellt förhållningssätt". Kursinnehållet rör ämnen som skillnaden mellan traditionellt och entreprenöriellt företagande och affärsplan med inriktningar mot kreativa organisationer.

Luleå tekniska universitet: Högskoleingenjör Datorspelsutveckling (180 ECTS) innehåller en kurs i entreprenörskap. Kursen ska ge studen- 
terna kunskap om grundläggande begrepp, entreprenörens betydelse för individ och samhälle samt fördjupa sig inom några utvalda områden inom entreprenörskap.

Stockholms universitet: Bachelorutbildningen Datorspelsutveckling (180 ECTS) innehåller en obligatorisk kurs Spel och entreprenörskap om 7,5 ECTS. Kursens syfte är att ge studenterna kunskap om hur man ta ett spel från idéstadiet till färdig produkt.

\section{Design, formgivning, mode}

Göteborgs universitet - Steneby, Institutionen för konsthantverk och design: Masterutbildningen vid Steneby innehåller ett gemensamt block för alla studenter dör ämnen som entreprenörskap och företagande ingår.

\section{Scenkonst, musik}

Dans och Cirkushögskolan: I bachelorutbildningen i Cirkusutbildning (180 ECTS) ingår kursen "Entreprenörskap, anställning och ekonomi" som omfattar 7,5 ECTS och är en orienteringskurs i ämnena eget företagande, arbetsrätt, marknadsföring etc.

Högskolan Dalarna: Utbildningsprogrammet Musik- och ljuddesign (120 ECTS) innehåller kurserna Företagsekonomi för musikbranschen, 7,5 ECTS, och Musikbranschen, 7,5 ECTS.

\section{Media (radio, TV, journalistik)}

Malmö högskola: Till programmen Produktionsledare - Media, Processdesigner - Media och Medieproduktion och processdesign (alla 180 ECTS) ingår kursen Grafisk affärverksamhet (15 ECTS). Kursens mål är att ge studenterna möjlighet att betrakta en nyinvestering ur ett helhetsperspektiv.

\section{Rörlig bild och foto}

Högskolan Väst: Filmproducentutbildningen (180 ECTS) innehåller en stor andel studier i företagsekonomi. Under de två första åren ingår sammanlagt 45 ECTS i ämnet, tredje året ingår 15 ECTS företagsekonomi.

Göteborgs universitet - Filmhögskolan: Masterprogram i Film (60 ECTS) innehåller ett ämnesblock om 15 ECTS som behandlar immaterialrätt, juridik, ekonomi och marknadskommunikation.

\section{Upplevelser}

Luleå Tekniska Universitet: Bachelorutbildningen Upplevelseproduktion (180 ECTS) innehåller obligatoriska kurser i ämnen som företagsekonomi, marknadsföring, marknadskommunikation, juridik etc. 


\subsection{Färöarna}

Den högre utbildningen på Färöarna karaktäriseras av att den i hög grad är yrkesinriktad och leder fram till kompetenser som är av direkt nytta för samhället, som t ex sjöfart och vård och omsorg. Färöarnas universitet erbjuder utbildning vid tre fakulteter, färöiska språket, naturvetenskap/teknik och historia/samhällsvetenskap. Antalet studenter vid universitetet är ca 130. Av tradition väljer ofta studenterna att förlägga hela eller delar av sin utbildning till andra länder.

Illustrationen nedan visar fördelningen av studenter mellan de tre utbildningsområdena år 2010.

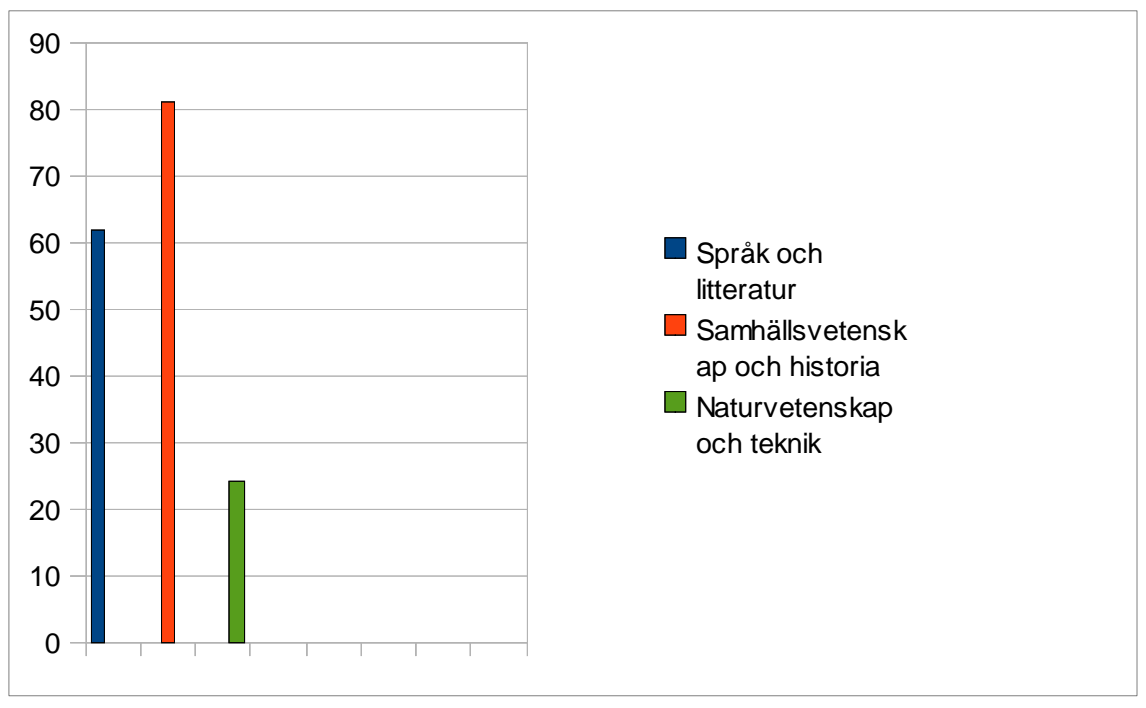

'Källa: Hagstova Føroya. ${ }^{19}$

${ }^{19}$ Hagstova Føroya. 



\section{Analys och diskussion}

\subsection{Entreprenörskapsutbildningens plats i utbildningarna}

Man kan urskilja tre olika typiska positioner som de befintliga entreprenörskapsutbildningarna har i utbildningsplanerna. Den första kategorin är de obligatoriska kurserna, som alla studenter inom utbildningsprogrammet måste ta del av. Den andra kategorin är de valbara kurser som erbjuds inom utbildningsområdet eller vid andra fakulteter eller utbildningsinstanser. Den tredje kategorin är de entreprenörskapssatsningar som sker utanför universitetet/högskolan i form av workshops, kurser, inkubatorer och liknande.

\subsubsection{Obligatoriska entreprenörskapskurser}

Ett gemensamt drag hos många av de obligatoriska kurserna i entreprenörskap är att de är anpassade till den verklighet som studenterna inom det specifika utbildningsområdet ställs inför. De utbildningsområden där man kan finna flest obligatoriska entreprenörskapskurser är interaktiva underhållningsprogram, upplevelser, film och musik.

Bland musikutbildningarna utmärker sig speciellt utbildningen $\mathrm{i}$ "Music Management" (180 ECTS) vid Rytmisk Musikkonservatorium i Köpenhamn där entreprenörskapskurser om hela 70 ECTS ingår. Kursernas innehåll spänner över flera viktiga aspekter, från praktiska frågor kring juridik och företagsstart till de mer teoretiska frågeställningarna som handlar om innovation. En liknande tendens kan ses hos filmutbildningarna i Norden där studiernas karaktär och studenternas kommande roll som producenter etc. naturligtvis kräver ingående kunskaper inom områden som ekonomi, juridik, skatteregler och liknande.

Mastersprogrammet "Serious Games" (60 ECTS) vid Högskolan i Skövde innehåller två utbildningsblock som berör entreprenörskap - "Affärsplanering" och "Entreprenörskap - villkor och särprägel" om vardera 7,5 ECTS. Inom denna utbildning koncentreras alltså $25 \%$ av kurserna på specifika, entreprenöriella egenskaper som studenterna behöver. 
"Spel och entreprenörskap" kallas den kurs om 7,5 ECTS som ingår i bachelor-utbildningen Datorspelsutveckling (180 ECTS) vid Stockholms universitet. Kursens utformning är direkt anpassad till spelutvecklarnas frågeställningar vad gäller att utveckla en produkt och introducera den på marknaden.

Den norska högskolan i Nord-Trøndelag och Universitet i Agder har båda implementerat entreprenörskapskurser i sina utbildningar inom spelutveckling och multimediedesign. Även om omfanget av kurserna inte är så stort ger de studenterna grundläggande kunskaper om företagande och de faktorer som särskiljer de kreativa näringarna.

IT-universitetet i Köpenhamn ger kursen "Innovation og iværksætteri" (5 ECTS) till studenterna på bachelorprogrammet Digitala medier och design.

På design och formgivningsområdet sticker Norge ut med ett stort antal entreprenörskapskurser för studenterna på området. Vid Høgskolen i Oslo ingår ett utbildningsblock fokuserat på entreprenörskap och företagande på sammanlagt 20 ECTS i alla bachelor-utbildningar vid avdelningen för estetiska ämnen. Universitetet i Agder ger en kurs i entreprenörskap (10 ECTS) inom ramen för bachelorprogrammet i Konstämnen, och vid Kunsthøgskolen i Oslo ingår kursen "Förmedling och etablering" (12 ECTS) i masterutbildningen inom ämnet Konstfack.

Även om många norska design och formgivningsutbildningar erbjuder kurser inom entreprenörskapsområdet, finns det även kurser som är mer svårdefinierade till sin natur. Exempel på det är "Estetik och produktion" inom bachelor-utbildningen i Produktdesign vid Høgskolen i Akershus och "Teknikförståelse och produktutveckling" som ingår i masterutbildningen "Produktdesign" vid samma högskola. Studenter vid bachelorutbildningen i Bildkonst vid Kunsthøgskolen i Oslo läser kursen "Professionalisering" (9 ECTS) som ger kunskap om skatteregler och liknande, men verkar lägga mest fokus på frågor kring stöd och stipendier. En sådan inriktning på utbildningen kan knappast bidra till en mer entreprenöriell anda hos studenterna.

I stort sett alla utbildningar inom upplevelseindustrin har tydligt inslag av entreprenörskap. Roskilde universitet erbjuder mastersutbildningen Oplevelseledelse (60 ECTS) som ger studenterna kunskap om företagande, samhälle och marknad samt upplevelseproduktion. I Finland kan man vid Yrkeshögskolan Novia läsa utbildningen Kulturproducentskap (240 ECTS) där praktiskt arbete i projekt varvas med teoretiska kunskaper om bl a entreprenörskap och ledarskap. 
Luleå Tekniska Universitet ger en bachelorutbildning i Upplevelseproduktion (180 ECTS) som innehåller kurser i företagsekonomi, marknadsföring, juridik etc. I Norge finns en uppsjö olika utbildningar inom upplevelsesfären, av vilka alla innehåller tydliga element av entreprenörskap, företagande, innovation och projektledning.

Utbildningarna som förbereder studenter för att verka inom upplevelseindustrin är till största delen förhållandevis nya, och industrin präglas av många olika företag. Dessa faktorer kan förklara den rika förekomsten av kurser som på ett handfast sätt förbereder studenterna för att driva och utveckla egna idéer och affärssatsningar.

\subsubsection{Valbara entreprenörskapskurser}

Valbara entreprenörskapskurser erbjuds vid många universitet. Ett nystartat exempel är projektledning och entreprenörskap för humanister (15 ECTS) vid Lunds universitet, som ska ge studenterna en bild av hur idéer kan utvecklas till affärsmöjligheter. Kursen har erbjudits i sin helhet vid ett tillfälle, och gett upphov till två företag. Enligt Jonas Josefsson, programansvarig för kursen, har den gett studenterna en möjlighet att "lära sig nytt, sett att egna idéer kanske inte är så dumma, lärt sig starta eget etc." 20

Södertörns högskola erbjuder en kompletterande kurs Kultur och entreprenörskap (15 ECTS) till studenter från estetiska inriktningar vid universitet och högskolor. Konstnärliga fakulteten vid Göteborgs universitet ger en sommarkurs kallas Att leva på sin konst (15 ECTS) som ska förbereda studenterna på yrkeslivet som konstnär.

De högskole-/universitetsövergripande satsningarna på entreprenörskap innehåller många kurser, workshops och föreläsningar med syfte att utveckla studenternas entreprenörskapsfärdigheter. Dessa satsningar karaktäriseras av att de är väldigt konkreta och förser studenterna med den kunskap och verktyg som behövs för att lyckas inom ämnen som innovation och näringsliv. En aspekt som kan påverka nyttan av dessa satsningar är att de vänder sig till studenter från flera olika utbildningsområden, och därför tvingas vara mer generella till sin natur. Det i sin tur kan innebära att vissa mer ämnesspecifika, men ytterst viktiga, frågeställningar inte tas upp.

${ }^{20}$ Josefsson, Jonas. E-post, 2010-09-20. 
Valbara kurser bygger helt och hållet på att studenterna gör ett aktivt val och ser sig själv som potentiella entreprenörer redan i ett tidigt skede. Det innebär naturligtvis att deltagarna på kurserna är motiverade och positivt inställda till det som lärs ut. Kanske de redan har företagsidéer vilande som de kan få genomförda tack vare kurserna. En risk är dock att studenter som inte har tänkt i banor runt entreprenörskap och innovation inte söker sig till kurserna. Deras eventuella entreprenörspotential riskerar därmed att förbli oupptäckt, och de ser inte möjligheterna att utvecklas i den riktningen. Tyvärr har rapportförfattaren inte hittat något underlag för andelen studenter som väljer att delta i de valbara entreprenörskapskurserna, information som vore mycket intressant att studera närmare.

\subsubsection{Externa entreprenörskapssatsningar}

Bland de externa entreprenörskapssatsningarna som erbjuds runt om i Norden ser det ut att finnas en mycket djup kunskap och insikt i de aktuella ämnena. Bland grundarna och genomförarna återfinns såväl drivna studenter, före detta studenter, entreprenörer och forskare inom området. Allt detta innebär att de aktiviteter som erbjuds håller hög kvalitet och har klara entreprenörsutvecklande mål.

I Danmark är IDEA en av de största aktörerna inom området. Med en stark förankring i universitetsvärlden och ett stort nätverk kan IDEA erbjuda studenter och utbildare insatser av hög kvalitet.

Norska Gründerskolen är ett samarbetsprojekt mellan alla universitet och ett antal högskolor med syfte att ge studenterna behövlig kompetens och en positiv inställning till entreprenörskap. Gründerskolen omfattar sammanlagt 30 ECTS och innehåller en inledande och avslutande kurs samt en tre månader lång praktikperiod utomlands. För att delta i Gründerskolen krävs att studenterna har avklarat minst en bachelor-utbildning.

Vid Handelshøyskolen BI i Oslo erbjuds bachelor-utbildningen Entreprenörskap (180 ECTS) som kan kombineras med flera konstnärliga och kreativa utbildningsområden. Målet är att studenterna efter avslutad utbildning ska kunna starta sin egen verksamhet.

Aalto Entrepreneurship Academy i Finland är en studentdriven organisation för studenterna vid Aalto-universitetet. Till deras verksamhet hör att skapa nätverk, coacha och anordna workshops. Helsinki Metropolitan Entrepreneurship Society är en liknande organisation som arbetar för att främja studenternas entreprenörskapskunnande. 
Isländska Klak är ett innovationscenter som erbjuder studenter utbildning i entreprenörskap. På Island finns även satsningen Keilir School of Creative Industries som i samarbete med Island universitet och Innovation Center of Iceland kopplar samman konst och entreprenörskap.

I Sverige är några exempel på externa satsningar på entreprenörskap bl a Business \& Design Lab vid Konstnärliga fakulteten vid Göteborgs universitet. Studenter med minst 150 ECTS avklarade studier kan söka in vid Entreprenörskapsutbildningen (60 ECTS) vid Högskolan i Skövde, där målet är att studenterna redan under utbildningen ska starta och driva företag. Enligt programansvarige Joachim Samuelsson vid Högskolan i Skövde är utfallet av utbildningen gott: ${ }^{21}$

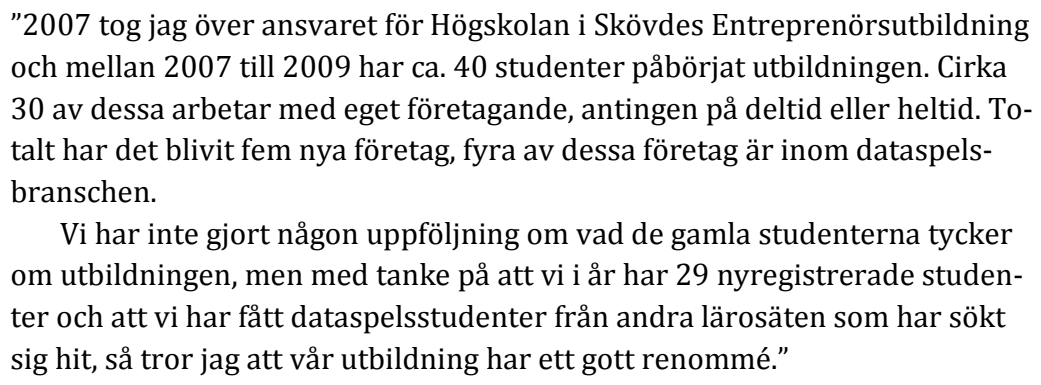

Vi har inte gjort någon uppföljning om vad de gamla studenterna tycker om utbildningen, men med tanke på att vi i år har 29 nyregistrerade studenter och att vi har fått dataspelsstudenter från andra lärosäten som har sökt sig hit, så tror jag att vår utbildning har ett gott renommé."

Stockholm School of Entrepreneurship erbjuder såväl fristående kompletterande kurser som ett program kallat Entrepreneurship and Innovation Management (60 ECTS).

Förutom de ovan nämnda satsningarna finns även inkubatorer och olika entreprenörskapstävlingar vid många universitet och högskolor. Många av de exempel som nämnts bygger på konkurrens, t ex Gründerskolen som använder sig av intervjuer och lämplighetstest för att avgöra vilka studenter som får delta i utbildningen. För att ta del i tävlingar och inkubatorer krävs att studenterna redan har en väl genomtänkt affärsidé som kan presenteras. För de studenter som har en gedigen grundläggande kunskap om entreprenörskap och kan formulera en affärsidé kan dessa format fungera ypperligt och ge studenterna både hjälp och uppmärksamhet. Man kan tänka sig att om fler studenter erbjöds grundläggande entreprenörskurser skulle fler av dem nå fram till de externa satsningarna och även bidra till en ökad mångfald bland de affärsidéer som kommer fram genom dem. 
En långvarig och väl förankrad satsning på entreprenörskap är danska KaosPiloterna, en treårig utbildning med säte i Århus. ${ }^{22}$ Utbildningen är projektbaserad och bygger långt på drivna studenter med god förmåga att tillvarata utbildningen och ta eget ansvar. KaosPilotutbildningen är godkänd av det danska ministeriet för vetenskap, teknologi och utveckling, men ger inte studenterna en akademisk examen enligt gängse mall. 


\section{Rekommendationer}

\subsection{Fortgående diskussion av begreppet entreprenör och entreprenörskap}

\subsubsection{Bakgrund}

Den svenska Nationalencyklopedin definierar begreppet entreprenör som en "person som i konkret handling skapar ny affärsverksamhet". I samband med materialinsamlingen för denna rapport visade det sig att de kurser i entreprenörskap som ingår i de högre utbildningarna skiljer sig åt innehållsmässigt. Entreprenörskap kan innebära allt från företagsstart, skatteregler och juridik till innovation och idéutveckling.

För att arbeta vidare kring frågan om entreprenörskap i utbildningen måste begreppet entreprenör och entreprenörskap diskuteras, analyseras och definieras. Ska begreppet innebära faktiska kunskaper kring hur en affärsrörelse startas och drivs eller är det intressant att titta på hur entreprenörskap kan ses som en färdighet av nytta för redan existerande organisationer? I vilken mån är och ska innovation och förmågan att tänka i nya banor och rubba jämvikten på marknaden vara viktigt inom entreprenörskapsutbildningarna? Ska studenterna främst ges färdigheter att försörja sig själva eller bör det inom ramen för entreprenörskap även finnas en tanke kring att studentens affärsidé kan leda till försörjningen av flera, eller många flera? För studenter vid högre utbildning är det även viktigt att det finns klarhet i vad en utbildning i entreprenörskap erbjuder.

\subsubsection{Innehåll}

Genom att analysera hur begreppet entreprenörskap används inom utbildningarna kan man ta ställning till om det behövs en gemensam överenskommelse kring vad entreprenörskapsutbildningar ska innehålla, eller om det diversifierade innehållet visar sig vara ett fungerade koncept. En klar kommunikation av studiernas innehåll borde uppmuntras gentemot studenterna, med syftet och målet med entreprenörskapsutbildningen tydligt definierade. Här är det även av intresse 
att närmare undersöka vad studenternas förväntningar är och vilket innehåll de tror sig behöva, och efter avslutade studier, vet sig behöva.

\subsubsection{Diskussion kring begreppen entreprenör och entreprenörskap}

Vidare studier av innehållet i entreprenörskapsutbildning behöver genomföras för att ytterligare kartlägga skillnader och likheter. För att kunna nå fram till en överenskommelse kring användningen av begreppet entreprenör och entreprenörskap är det av vikt att studenternas förväntningar av studierna undersöks, dels hos studenter som går utbildningarna, dels hos studenter som avslutat sina utbildningar.

\subsection{Utfallet av entreprenörskapsutbildning}

\subsubsection{Bakgrund}

Idag finns det ytterst lite underlag som kan visa på i vilken mån entreprenörskapsutbildning leder till fler nystartade företag, fler produktlanseringar etc. Bland annat i en rapport från SCB påpekas att personer med examina i konstnärliga ämnen inte lyckas hitta sin plats på arbetsmarknaden i samma utsträckning som personer med examina inom andra områden. Dock saknas statistik som visar om entreprenörskapsatsningar leder till att de utexaminerade studenterna klarar sig bättre på arbetsmarknaden.

\subsubsection{Innehåll}

Genom att undersöka hur arbetssituationen ser ut bland studenter som deltagit i entreprenörskapssatsningar av olika slag kan en bild av vilka satsningar som är de mest effektiva fås fram. Detta underlag kan sedan användas för att bestämma vilka typer av entreprenörsutbildningar som är värda att ytterligare utveckla och satsa på. En viktig fråga i sammanhanget är att se på resultatet utifrån olika tidsperspektiv - vad har hänt efter ett respektive fem år? 


\subsubsection{Utveckling av utfallet av entreprenörskapsutbildning}

För att få en så bred bild av utfallet som möjligt är det av vikt att först och främst analysera de olika formerna av entreprenörskapsutbildning och -satsningar som finns vad gäller innehåll, omfång, tillgänglighet etc. Studenter som genomgått utbildningarna kontaktas och deras situation på arbetsmarknaden kartläggs, liksom deras övriga entreprenöriella egenskaper, som innovationsbenägenhet, framtidsplaner etc. Genom att analysera resultatet av en sådan undersökning kan ett resultat av de olika satsningarnas framgångsgrad tas fram.

\subsection{Arbete för ökat intresse för entreprenörskap}

\subsubsection{Bakgrund}

Efter en genomgång av de entreprenörskapsutbildningar som erbjuds vid konstnärliga och kreativa utbildningarna vid universitet och högskolor i Norden kan man snart se ett mönster gällande utbudet. Inom många av de nyare ämnena, som t ex upplevelser, spelutbildningar och kulturproducentutbildningar ingår kurser i företagande, juridik, ekonomi etc. Inom de traditionella ämnena som litteraturvetenskap, estetik, musikvetenskap och liknande förekommer den här typen av entreprenörsgynnande inslag mycket mer sparsamt och bygger ofta på att studenterna av eget initiativ ska söka sig till fristående kurser inom ämnet.

Nyare ämnen, som tidigare nämnda upplevelser och spelutveckling, drivs ofta av personer med erfarenhet av branschen och entreprenörskap. Det innebär naturligtvis att frågor som företagande får en plats $i$ kursplanen. Vissa högskolor och universitet har även valt att profilera sina satsningar på entreprenörskap och utvecklat samarbeten med andra aktörer. Ett exempel på det är Konstfack som ingår i Stockholm School of Entrepreneurship och genom det samarbetet kan erbjuda sina masterstudenter kurser i företagande och entreprenörskap vid t ex Handelshögskolan och Kungliga Tekniska Högskolan.

\subsubsection{Exempel på innehåll}

Förståelsen för entreprenörskap och vikten av undervisning i ämnet varierar kraftigt mellan olika utbildningsinstanser. Detta beror naturligtvis på bl a den ojämna fördelning av anslag för studenter på de olika utbildningarna, vilket i sin tur leder till att möjligheterna att förändra 
eller utöka kursplanerna är begränsad. Dock kan en upplysande verksamhet leda till att intresset och förståelsen bland utbildarna växer. Denna verksamhet föreslås bestå av ett nätverksbyggande mellan de nordiska utbildningarna för att klargöra behov och möjligheter. Kurser om att undervisa i entreprenörskap erbjuds utbildare i samarbete med redan etablerade aktörer som IDEA i Danmark. Material om entreprenörskap framställs, både riktat till utbildare och studenter.

\subsubsection{Utveckling av arbete för ökat intresse för entreprenörskap}

Ett samnordiskt nätverk skapas med huvudaktörerna inom området, t ex IDEA, Öresund Entrepreneurship Academy, Kaospiloterne, Gründerskolen i Norge, HMEA och Innoplaza i Finland och representanter för de universitet och högskolor som redan idag driver framgångsrika entreprenörskapsutbildningar. Genom att knyta samman dessa aktörer tar man tillvara den kunskap som redan finns inom områden och kan isolera de olika delar inom området entreprenörskap som är relevant beroende på vilka studenter och utbildare man vill vända sig till. Detta nätverk träffas och arbetar fram riktlinjer och metoder för att öka andelen entreprenörskap i konstnärliga och kreativa utbildningar. En koordinator får i uppdrag att sammankalla och administrera arbetet, samt sammanställa material.

Genom de resurser som samlas inom ramen för ett samnordiskt nätverk erbjuder kan kurser i att undervisa i entreprenörskap erbjudas, förslag på kursinnehåll tas fram och material produceras. Erfarenheter av t ex genomförda workshops och föreläsningsserier delas och färdiga koncept för entreprenörsgynnande insatser tas fram.

\subsection{Universitets- och högskoleövergripande entreprenörssatsningar}

\subsubsection{Bakgrund}

I Danmark och Finland förekommer flera exempel på entreprenörssatsningar som inte är bundna till enskilda universitet eller högskolor. Dessa satsningar är lokaliserade till områden med en hög andel studenter och erbjuder dem entreprenörs- och innovationsgynnande kurser, workshops etc. 
I Finland erbjuder HMEA (Helsinki Metropolitan Entrepreneurship Academy) entreprenörsprogram för studenter i huvudstadsregionen. Handelshögskolan, Tekniska högskolan och Konstindustriella högskolan har skapat det gemensamma Aalto-universitetet, genom vilket studenterna vid de tre högskolorna erbjuds kurser i entreprenörskap och innovation.

IDEA är ett danskt kompetenscentrum inom entreprenörskap som administreras av Syddanskt universitet. Ett stort antal danska universitet ingår i IDEA-samarbetet och studenterna kan ta del av IDEAs programutbud. Øresund Entrepreneurship Academy är ett samarbete mellan de nio universiteten i Öresundsregionen, som erbjuder rådgivning och stöd för lärosätena.

\subsubsection{Exempel på innehåll}

Finska HMEA erbjuder studenterna en serie föreläsningar kring entreprenörskap som kallas Entrepreneur Tuesday. I deras program ingår även workshops kring ämnen som affärsutveckling, idéutveckling och försäljning.

Aalborg Universitet anordnar bl a en workshop under namnet WOFIE, där näringsutveckling, försäljning och innovation ingår. Danska IDEA har publicerat boken "Entreprenørskab i teori og praksis" med handfasta tips till studenter som är intresserade av att starta egna företag. Øresund Entrepreneurship Academy erbjuder handledning för lärare vid högskolor och universitet med syfte att stärka deras förmåga att självständigt undervisa i entreprenörskap.

\subsection{Utveckling av högskole- och universitetsövergripande satsningar}

De olika samarbeten som finns kring entreprenörskap och innovation bygger på att individer med stor kunskap inom ämnet bygger upp en institution som arbetar fram väl fungerande arbetsmetoder baserade på best practise-erfarenheter. Dessa samarbeten kunde utvecklas och innefatta fler högskolor och universitet på en nordisk nivå.

Ett förslag som gynnar utvecklingen är att utse en koordinator eller skapa ett nätverk med uppgift att kartlägga de satsningar som finns idag och studera deras arbetssätt. Genom att knyta andra relevanta utbildningsinsatser inom Norden till sig, kan koordinatorn/nätverket bistå med att sprida $t$ ex IDEAs och HMEAs idéer och kunskap samt 
knyta nya aktörer till satsningarna för att säkerställa att de nationella skillnaderna inom t ex juridik tillvaratas.

\subsection{Renodlad entreprenörskapsutbildning}

\subsubsection{Bakgrund}

Även om behovet av innehållet i entreprenörskapskurser skiljer sig åt beroende på vilket ämne studenterna studerar, finns det alltid grundläggande kunskaper som kan vara av nytta för alla. Det gäller framförallt frågor som skatt, företagsetablering etc. Vid Universitetet i Oslo erbjuds en kurs i entreprenörskap som omfattar 10 ECTS. Kursen är tillgänglig för alla studenter vid universitetet och ger en teoretisk och praktisk inblick i de olika aspekterna av företagsutveckling. I kursen belyses också hur universitet och näringsliv kan knytas samman.

\subsubsection{Exempel på innehåll}

- Skatteregler.

- Företagsetablering.

- Immaterialrätt.

- Innovation.

- Idéutveckling.

- Nätverksbyggande.

\subsubsection{Utveckling av renodlade entreprenörskapsutbildningar}

Genom ett nätverk eller en koordinator kan innehållet i en allmän entreprenörskapskurs sammanställas och anpassas så att innehållet är relevant för studenter från så många olika ämnesområden som möjligt. Till nätverkets/koordinatorns uppgifter hör också att arbeta för att flera universitet erbjuder kursen till sina studenter och att den aktivt marknadsförs till studenterna på de konstnärliga/kreativa utbildningarna. 


\section{7 Ämnesanpassad entreprenörskapsutbildning}

\subsubsection{Bakgrund}

Vid Högskolan i Oslo ingår ett obligatorisk block om entreprenörskap och företagande omfattande 20 ECTS för alla studenter vid avdelningen för estetiska ämnen. Ämnet läses under bachelorutbildningens sista år och omfattar entreprenörskap, projektarbete och företagande.

IT-universitetet i Köpenhamn satsar på att utveckla studenternas förmåga att utveckla egna affärsidéer. I bachelorutbildningen i Digitala medier och design ingår kursen "Innovation og iværksætteri" om 5 ECTS. Kandidatutbildning i samma ämne innehåller kursen "Innovation, konceptutveckling och projektstyrning" om 7,5 ECTS.

Vid Dans- och cirkushögskolan i Stockholm ingår entreprenörsskapskurser i alla grundutbildningar. Kursernas omfång varierar mellan 7,5-10 ECTS beroende på studenternas inriktning.

\subsubsection{Exempel på innehåll}

Beroende på vilket studentens huvudämne är, anpassas naturligtvis kursens innehåll. Kursen "Innovation og iværksætteri" vid ITuniversitetet i Köpenhamn tar upp frågor kring att ta en idé vidare till en digital produkt och därifrån till en säljbar produkt eller en företagsidé.

Kurserna i entreprenörskap vid Dans- och cirkushögskolan tar även upp t ex kulturpolitik, eftersom deras studenter ofta är beroende av kulturpolitiska beslut i sitt yrkesutövande.

Exempel på relevant innehåll är innovation, immaterialrätt, samarbeten, kulturpolitik, konceptutveckling etc.

\subsubsection{Utveckling av ämnesanpassad entreprenörskapsutbildning}

En koordinator/nätverk arbetar för att knyta de olika utbildningarna till sig och fastslå på vilka områden entreprenörskaputbildningen behöver anpassas beroende på studenternas inriktning. Ett nära samarbete med aktörer inom de olika områdena klargör vilka de viktigaste frågorna är för de olika studieinriktningarna och förslag på kursinnehåll sammanställs och distribueras till de olika utbildningarna. Genom ett nätverk som besitter goda kunskaper och insikt i entreprenörskapsrelaterade frågor kan ett förslag på kursinnehåll göras relativ 
okomplicerad och precist för att undvika extraarbete för utbildarna på berörda universitet och högskolor.

\subsection{Studentdrivna entreprenörskapssatsningar}

\subsubsection{Bakgrund}

Helsinki Metropolitan Entrepreneurship Academy är ett entreprenörsprogram som drivs av och för studenter. Kurser, föredrag och workshops är öppna för alla intresserade studenter och innehållet i dem anpassade för att passa personer som ännu studerar men är intresserade av att ta sina idéer ut i affärslivet. Helsinki Metropolitan Entrepreneurship Academy grundades på initiativ av det finska utbildningsministeriet.

\subsubsection{Exempel på innehåll}

Genom studentdrivna entreprenörskapssatsningar kan information om vilken typ av innehåll som efterfrågas samlas in av studenterna själva. Programmet kan bestå av föreläsningsserier anpassade utifrån olika studenters behov, entreprenörskapsfrämjande informationsförmedling ute på högskolor och universitet och en möjlighet för studenterna själva att påverka studieupplägg och innehåll.

\subsubsection{Utveckling av studentdrivna entreprenörskapssatsningar}

Genom att dra nytta av aktörer som HMEA kan ett nätverk för studenter med intresse för att främja och synliggöra entreprenörskap bildas. En sammanhållande aktör utses, med ansvar för att studenter från alla olika universitet och högskolor erbjuds möjlighet att ingå i nätverket. Deltagarna i nätverket träffas regelbundet för att lägga upp strategier och utbyta erfarenheter, förslagsvis en gång per termin landsvis och årligen till ett samnordiskt möte. 


\subsection{Sammanfattning av rekommendationer}

Termen entreprenörskap behöver fortsättningsvis diskuteras och preciseras. I studieplanerna används termen entreprenörskap för att beskriva en mängd olika färdigheter som projektledning, affärsutveckling, innovation med mera. Det är av yttersta vikt att man enas om en gemensam terminologi för att kunna utveckla nya, funktionella "policies".

Idag finns det nästan ingen information om utfallet av de tillgängliga entreprenörskapsutbildningarna och -satsningarna. För att bestämma innehållet i framtida entreprenörskapskurser, behöver en sammanställning och analys göras av utfallet av redan existerande utbildningar.

Konceptet entreprenörskap behöver presenteras och marknadsföras, speciellt gentemot de mer traditionella utbildningsområdena. $\mathrm{Om}$ det presenteras på ett sätt som synliggör fördelarna av entreprenörskapsstudier ökar sannolikheten för att de får en plats i utbildningsplanerna.

Innehållet i entreprenörskapsstudier varierar, och en fortsatt diskussion krävs för att enas kring innehållet. Inom vissa utbildningsområden kan en mer generell profil på entreprenörskapskurserna fungera, medan andra behöver en mycket mer specificerad inriktning.

För att utveckla entreprenörskapsutbildningarna och hitta nya samarbetsmöjligheter behövs ett samnordiskt nätverk. Deltagarna i nätverket ska ha goda kunskaper från den akademiska världen och existerande entreprenörskapssatsningar. Syftet med nätverket är att diskutera de frågeställningar och rekommendationer som presenterats ovan, samt att ta del av varandras kunskap och erfarenhet. Genom att genomföra detta kan en analys av "best practice" i metoder göras, som sedan kan fungera som en struktur att bygga entreprenörskapsstudier och entreprenörsskapssatsningar runt. 



\section{Referenser}

\section{Tryckta källor}

Gullander, S., Karlsson, S., Lundqvist, J., Lönnroth, S. \& Strandqvist, N. (2005). Att leva på sin talang - kreatörens behov av entreprenörskap. Stockholm: KKstiftelsen.

Clews, D. (2007). Creating Entrepreneurship: entrepreneurship education for the creative industries. Brighton: Higher Education Academy Art, Design, Media Subject Centre.

Fleming, T. (2007). A Creative Economy Green Paper for the Nordic Region. Copenhagen: Nordic Council of Ministers.

Nordic Innovation (2008). Creative Industries education in the Nordic countries - A brief portrait. Copenhagen: Nordic Council of Ministers.

\section{Elektroniska källor}

Danmarks statistik. http://www.dst.dk/

European Commission. Enterprise and industry directorate-general (2008). Entrepreneurship in higher education, especially within non-business studies, 2008:3. European Commission. http://www.emuni.si/Files/knjiznica/78_ECEntrepreneurship-in-Higher-Education-2008.pdf (Hämtad 2010-11-03).

Fonden for Entreprenørskab (2010). Strategi for Fonden for Entreprenørskab 2010-2015. http://www.fondenforentreprenoerskab.dk/fileadmin/brugerfiler/dokumenter/St rategi_for_Fonden_for_Entreprenoerskab_ENDELIG.PDF (Hämtad 2010-11-03).

Fonden for Entreprenørskab (2010). Entreprenørskab fra ABC til ph.d. 2009-2010.

http://www.fondenforentreprenoerskab.dk/index.php?id=188 (Hämtad 2010-12-08).

Hagstova Føroya. http://www.hagstova.fo

Hagstofa Íslands. http://www.hagstofa.is/

Högskoleverket. http://www.hsv.se/

KaosPilot http://www.kaospilot.dk

Statistisk Sentralbyrå. http://www.ssb.no/

Statistiska centralbyrån (2007). Tema: Utbildning. Sambandet mellan utbildning och yrke. En studie om högskoleutbildningar. 2007:1. Statistiska centralbyrån. http://www.scb.se/statistik/_publikationer/UF0504_2007A01_BR_UFFT0701.pdf (Hämtad 2010-11-03).

The official Bologna Process website July 2007-June 2010.

http://www.ond.vlaanderen.be/hogeronderwijs/bologna/actionlines/employabili ty.htm (Hämtad 2010-11-03).

Tilastokeskus. http://www.stat.fi/ 
Tillväxtverket (2010). Entreprenörskap i kulturella och kreativa utbildningar (ej publicerad 2010-11-03). http://www.tillvaxtverket.se/huvudmeny/programfortillvaxt/ kulturellaochkreativanaringar.

Tillväxtverket (2010). http://www.tillvaxtverket.se/sidfot/amnesomraden/ entreprenorskap.4.21099e4211fdba8c87b800017627.html (Hämtad 2010-11-03).

Wikipedia (2010). Joseph Schumpeter.

http://sv.wikipedia.org/wiki/Joseph_Schumpeter (Hämtad 2010-11-03). 


\section{Summary in English}

\section{Purpose}

The purpose of the study is divided into three different areas. The first one is to map studies in entrepreneurship available to students in higher artistic and creative education in the Nordic region. The educational institutions included are universities and colleges in the Nordic countries and the Faroe Islands.

The second area consists of finding good examples of entrepreneurship studies and to discuss these in comparison with the available studies.

The third area consists of recommendations based on the result from the mapping. These recommendations will be used as a foundation for KreaNord's future policies concerning entrepreneurship in higher artistic and creative education.

\section{Results}

Integrated entrepreneurship education is more often found in the fields of interactive software, the experience industry, and film. These educational fields share the characteristics of being relatively young and therefore one can assume that the curricula are adjusted to the reality the students will face after completing their studies.

Students at the artistic educations are more likely to be offered optional courses in entrepreneurship. These courses may be aimed directly at students of the specific field, or have a more general entrepreneurial profile. A potential risk linked to optional courses is that students who don't see themselves as entrepreneurs most likely will choose not to attend the courses, hence missing the opportunity to discover the benefits of thinking in an entrepreneurial way about themselves and their ideas.

External entrepreneurship ventures share the characteristics of being of very high quality and run by individuals and/or organizations with exceptional skills in entrepreneurship. Participation in these ventures is often based on students competing for a place, and on the students' perception of themselves as entrepreneurs. 


\section{Recommendations}

The concept of entrepreneurship needs to be discussed and further pinpointed. In the curricula the term entrepreneurship is used to describe a number of different skills, such as project management, business development, innovation etc. It is crucial to decide on a common content of the term, in order to develop functional, new policies.

To this day, there's is almost no available data on the outcome of the available entrepreneurship studies and ventures. In order to decide on the content of future entrepreneurship studies, an analysis should be done, comparing the outcome of existing entrepreneurship studies.

The concept of entrepreneurship needs to be marketed and presented, especially within the more traditional educational fields. If presented in a way that makes the benefits of entrepreneurship studies obvious, the likeliness of it being a part of the curriculum increases.

The content of entrepreneurship studies varies, and further discussion is needed to decide on the form of entrepreneurship studies. Certain educational fields may benefit from a more general profile, while others may need a very specific orientation.

In order to develop entrepreneurship studies and find new collaborations, a Nordic network is needed. The network should consist of individuals with specific knowledge from the academic world and existing entrepreneurship ventures. The aim of the network should be to discuss all the actions described above and share their common knowledge and experience. By doing this, an analysis of best practice methods can be done, and entrepreneurship studies and ventures can be structured around them. 


\section{Bilagor}

\section{Webadresser till i rapporten förekommande entreprenör-skapssatsningar för studenter vid universitet och högskolor}

\section{Danmark}

- IDEA: http://www.idea-denmark.dk/

- Øresund Entrepreneurship Society: http://www.oeacademy.org/

- SEA: http://www.sea.aau.dk/

- Aarhus Entrepreneurship Centre: http://aec.au.dk/

- Arkitektskolen Aarhus - KarriereVærkstedet: http://karrierevaerkstedet.aarch.dk/

- Danmarks Designskole: http://www.dkds.dk/

- Designskolen Kolding: http://www.designskolenkolding.dk/

- Köpenhamns universitet - Summer School in Entrepreneurship: http://www.econ.ku.dk/polit/summerschool/entrepreneurship/

- Köpenhamns universitet - Katalyst: http://katalyst.hum.ku.dk/

- RUCInnovation: http://magenta.ruc.dk/rucinnovation/

- DTU Symbion Innovation: http://www.dtusymbioninnovation.dk/

- WOFIE: http://www.wofie.aau.dk/

\section{Finland}

- Boost Turku: http://www.boostturku.com/

- Aalto Entrepreneurship Society: http://aaltoes.com/

- Aalto-universitetet: http://www.aalto.fi/

- HMEA: http://hmea.fi/

- Innoplaza: http://innoplaza.metropolia.fi/

- Arcada: http://www.arcada.fi/ 


\section{Island}

- Klak: http://www.klak.is/

- Keilir School of Creative Industries: http://www.keilir.net/

- Innovit: http://www.innovit.is/

\section{Norge}

- Handelshøyskolen BI - Entreprenörskap: http://www.innovit.is/

- Gründerskolen: http://www.grunderskolen.no/

- Universitetet i Bergen - Nyskapingsparken: http://nyskapingsparken.no/

- Universitetet i Stavanger - Senter for entreprenørskap: http://www.uis.no/category.php?categoryID $=6040$

- NTNU - Innovasjonssenter Gløshaugen: http://www.ntnu.no/ig

- Bergen Designinkubator: http://www.bergendesigninkubator.no/

- Høgskolen i Buskerud - SeIE: http://www.hibu.no/seie

\section{Sverige}

- Stockholm School of Entrepreneurship: http://www.sses.se/

- Göteborgs universitet - Konsten att leva på sin konst: http://levapasinkonst.wordpress.com/

- Göteborgs universitet - Business \& Design Lab: http://www.hgu.gu.se/item.aspx?id=11446

- Högskolan i Skövde - Entreprenörsutbildningen: http://utbildning.his.se/Programtillfalle.aspx?PtKod=EPRUG09h

- Lunds universitet - Projektledning och entreprenörskap för humanister: http://www.kultur.lu.se/utbildning/projektledning-ochentreprenoerskap-foer-humanister

- Södertörns högskola - Kultur \& entreprenörskap: http://webappl.sh.se/C1256FD90044C57C/tmt.view/73BF1F4E6D4 B4199C12574BA0031C337

- Blekinge Tekniska Högskola - BTH Innovation Business Lab: http://www.bth.se/innovation/bth-innovation.nsf/sidor/business-lab 
Ved Stranden 18

DK-1061 København K

www.norden.org

\section{Entreprenörskap i högre konstnärlig och kreativ utbildning i Norden}

Denna rapport, utfört av Nordic Game Resources för KreaNord i 2010, består av tre delar. Det första området är en kartläggning av förekomsten av entreprenörskapsutbildning som är tillgänglig för studenter vid högre konstnärliga och kreativa utbildningar $i$ Norden. Det andra området innebär att hitta goda exempel på entreprenörskapsutbildningar och diskutera dessa i jämförelse med det övriga utbudet. Studiens tredje område består av rekommendationer som kan användas i arbetet med att skapa policies för entreprenörskap inom högre konstnärlig och kreativ utbildning.

Återpublicerad 2015 i samband med avvecklingen av KreaNord, Nordiska ministerrådets initiativ för kulturella och kreativa näringar (2008-2015). 